\title{
Sedimentological analyses of martian gullies: The subsurface as the key to the surface
}

\author{
Tjalling de Haas ${ }^{\mathrm{a}, *}$, Dario Ventra ${ }^{\mathrm{a}}$, Ernst Hauber ${ }^{\mathrm{b}}$, Susan J. Conway ${ }^{\mathrm{c}}$, Maarten G. Kleinhans ${ }^{\mathrm{a}}$ \\ ${ }^{a}$ Faculty of Geosciences, Utrecht University, PO-Box 80115, 3508 TC Utrecht, The Netherlands \\ ${ }^{\mathrm{b}}$ Institute of Planetary Research, German Aerospace Center, Rutherfordstrasse 2, DE-12489 Berlin, Germany \\ ${ }^{c}$ Department of Physical Sciences, Open University, Walton Hall, Milton Keynes MK7 6AA, UK
}

\section{A R T I C L E I N F O}

\section{Article history:}

Received 23 January 2015

Revised 4 May 2015

Accepted 12 June 2015

Available online 19 June 2015

\section{Keywords:}

Mars, surface

Mars, climate

Mars, atmosphere

\begin{abstract}
A B S T R A C T
Gullies are among the youngest landforms formed by liquid water on Mars, and therefore of critical importance in resolving the planets most recent hydrologic and climatic history. Water-free sediment flows, debris flows and fluvial flows have all been identified in gullies. These processes require very different amounts of liquid water, and therefore their relative contribution to gully-formation is of key importance for climatic inferences. We show that many gullies dominantly formed by debris flows, based on sedimentological analysis of outcrops in gully-fans in 51 HiRISE images widely distributed over the southern midlatitudes. The great majority (96\%) of outcrop exposures in gully-fans fed by catchments which mainly comprise bedrock and thus host boulders, contain sedimentological evidence for debris-flow formation. These exposures contain many randomly distributed large boulders $(>1 \mathrm{~m})$ suspended in a finer matrix and in some cases lens-shaped and truncated layering. Such diagnostic features are rare in gully-fan exposures mainly fed by catchments comprising abundant latitude dependent mantle deposits (LDM; a smooth, often meters-thick deposit consisting mainly of ice and dust), wherein boulders are largely absent. These LDM-fed gullies may have formed by fine-grained debris flows, but this cannot be determined from outcrop sedimentology alone because of the lack of boulders in these systems. The fan surface morphology, in contrast to the subsurface, is dominated by secondary, post-depositional, processes, mainly weathering, wind erosion, and ice-dust mantling. These processes have removed or severely reworked the original, primary, debris-flow morphology over time. This explains the controversy between previously published morphometric analyses implying debris-flow formation and observations of gully-fan surfaces, which are often interpreted as the product of fluvial flows because of the absence of surficial debris-flow morphology. The inferred debris-flow origin for many gullies implies limited and ephemeral liquid water during gully-formation.
\end{abstract}

(c) 2015 Elsevier Inc. All rights reserved.

\section{Introduction}

Martian gullies are composite landforms that comprise an alcove, channel and depositional fan (Malin and Edgett, 2000). They are very young geological features, some of which have been active over the last million years (Reiss et al., 2004; Schon et al., 2009; Johnsson et al., 2014). The different processes proposed for the formation of martian gullies vary greatly in terms of involved liquid water volumes and duration of liquid water at the planet's surface. They range from dry sediment-gravity flows which require no water, to debris flows wherein water contents generally range between $20 \%$ and $60 \%$ on Earth (e.g., Costa, 1988; Pierson, 2005),

\footnotetext{
* Corresponding author.

E-mail address: t.dehaas@uu.nl (T. de Haas).
}

and fluvial flows that require sustained water volumes that are orders of magnitude larger (e.g., Costa, 1988). These landforms are thus of critical importance for understanding the recent hydrology and climate at the martian surface, but their formative mechanisms have been heavily debated since their discovery (Malin and Edgett, 2000). Evidence for water-free sediment flows, often associated to $\mathrm{CO}_{2}$ ice, (e.g., Treiman, 2003; Pelletier et al., 2008; Dundas et al., 2010, 2014; Cedillo-Flores et al., 2011), debris flows (e.g., Costard et al., 2002; Hartmann et al., 2003; Levy et al., 2010; Lanza et al., 2010; Johnsson et al., 2014; De Haas et al., 2015b) and fluvial flows (dilute or hyperconcentrated) (e.g., Heldmann and Mellon, 2004; Heldmann et al., 2005; Dickson et al., 2007; Head et al., 2008; Levy et al., 2009b; Reiss et al., 2011) has been recognized on gullies, but the relative contribution of these processes to gully formation appears to differ among sites. The 
morphometry of most gullies is consistent with dominant formation by liquid water (e.g., Mangold et al., 2010; Conway et al., 2011; Johnsson et al., 2014; Yue et al., 2014), probably supplied by melting of snow/ice in alcoves (e.g., Costard et al., 2002; Christensen, 2003; Dickson and Head, 2009) during glacial periods forced by high orbital obliquity (Christensen, 2003; Head et al., 2003). In contrast, in other gullies new deposits have formed over the last decade, in spite of lacking evidence for liquid water on the present martian surface suggesting sediment transport unrelated to liquid water (e.g., Dundas et al., 2010, 2014).

Many authors inferred that most gullies were formed by fluvial flows because the surface morphology of most gully-fans lacks evidence for debris-flow processes (e.g., Dickson and Head, 2009; Levy et al., 2009b; Reiss et al., 2011). Paired levees, distinct depositional lobes and outsized boulders (meter-sized boulders that are much larger than the surrounding sediments), all characteristic of debris-flow deposits, are only recognizable on a few fans (e.g., Lanza et al., 2010; Levy et al., 2010; Johnsson et al., 2014) but are generally not reported (e.g., Dickson and Head, 2009; Reiss et al., 2011; Johnsson et al., 2014). Nevertheless, the morphometric attributes of these gully-fans do suggest a formation by debris flows: slope-area relations (Lanza et al., 2010; Conway et al., 2011), gully width-depth relations (Yue et al., 2014), channel sinuosity (Mangold et al., 2010), the short length of gullies (Heldmann et al., 2005) and the often steep depositional slopes of the fans $\left(>15^{\circ}\right)$ (e.g., Heldmann and Mellon, 2004; Dickson et al., 2007; Lanza et al., 2010; Levy et al., 2010; Conway et al., 2015).

On Earth, fans on which primary processes of aggradation have been long inactive are exposed to prolonged weathering and erosion. These secondary processes often dominate fan surfaces due to the long return periods of primary processes, although they generally have a minimal effect on fan aggradation (Blair and McPherson, 1994). As such, secondary processes modify the surface and hinder identification of primary depositional processes based solely on surface morphology (e.g., Hartley et al., 2005; Blair and McPherson, 2009; De Haas et al., 2013, 2014). We hypothesize, therefore, that post-depositional modification of martian gully-fan surfaces may explain the discrepancy between surficial traits, implying gully formation by fluvial flows, and morphometric properties indicative of debris flows. The origin of long-inactive and modified fans can be determined by sedimentological analyses of stratigraphic exposures, because deposits are generally reworked at their upper surface, but not internally (e.g., Blair and McPherson, 1994; De Haas et al., 2014). Such an approach has recently been successfully employed on an alluvial fan in Gale crater using Curiosity rover images (Williams et al., 2013). However, stratigraphic analyses are not obviously feasible for Mars, where most outcrops can solely be examined from satellite images. Yet, recent high-resolution HiRISE images (High Resolution Imaging Science Experiment; $\sim 0.25 \mathrm{~m} / \mathrm{px}$ ) enable the recognition of large boulders and large-scale stratigraphic layering in sedimentary outcrops on Mars (e.g., Grotzinger and Milliken, 2012).

Here, we aim to constrain the formative processes of martian gullies based on outcrop sedimentology. Secondly, we aim to resolve the apparent discrepancy between genetic interpretations from gully-fan surface and morphometry.

We found many well-exposed outcrops along deeply incised channels on HiRISE images of martian gully-fans, showing the presence of large boulders and large-scale layering patterns. These key diagnostic features were used to determine the formative processes of gullies from outcrop sedimentology, by comparison to terrestrial analogs. $\mathrm{CO}_{2}$-driven dry flows do not occur at the physical conditions encountered on Earth's surface, so comparison with terrestrial analogs is not possible for these flows. Our survey focuses on gullies that probably formed in the presence of liquid water. Therefore, gullies with morphological and morphometric characteristics indicative for dominant rockfall or grainflow processes are excluded from the present work, i.e., very steep fans, near the angle of repose, with relatively shorter radial lengths than debris-flow fans and fluvial fans, a downslope coarsening texture and topographically smooth surfaces (e.g., Blikra and Nemec, 1998; Blair and McPherson, 2009). To provide the necessary background for the sedimentological-stratigraphic analysis, a brief summary of morphometric, morphological and sedimentological-stratigraphic characteristics of terrestrial deposits formed by debris flows and fluvial flows is first provided. After a description of study material and methods, a combined stratigraphic, morphological and morphometric analysis of martian southern mid-latitude gullies forms the basis to discuss their formative processes.

\section{Primary alluvial fan morphology and stratigraphy}

Debris flows are dense, non-newtonian, mixtures of sediment and water, typically containing $20-60 \%$ water by volume (e.g., Costa, 1988; Iverson, 1997; Pierson, 2005). Outsized boulders with diameters up to several meters are easily transported for hundreds of meters by debris flows over depositional fan slopes (e.g., Pierson, 1980; Whipple and Dunne, 1992; Vallance and Scott, 1997), mainly because of the relatively small difference in density between individual boulders and the debris-flow mixture (Fig. 1a and b). In stratigraphy, debris-flow deposits are generally internally massive, comprising gravel and outsized boulders randomly dispersed and generally randomly oriented in a finer matrix (e.g., Fisher, 1971; Blair and McPherson, 1994; Major, 1997; Blikra and Nemec, 1998; Blair and McPherson, 2009) (Fig. 1a and b). In general, stacked deposits appear structureless and amalgamated, hampering the recognition of individual units, but bedding can be evident from secondary reworking of the exposed boundaries of original depositional units (e.g., Blair and McPherson, 1994; Blair, 1999). Individual depositional units are typically quasi-tabular to slightly irregular, subparallel to the depositional surface and continuous over distances up to several hundreds of meters in slope-oriented sections. Locally they are sharply tapering or pinching out where the section intersects original lobe margins. In slope-transverse sections debris-flow deposits appear as laterally tapering or truncated plano-convex lenses, possibly with concentrations of coarser debris at the margins, corresponding to lateral levees and frontal snouts (Suwa, 1988; Hubert and Filipov, 1989; Johnson et al., 2012). In planform, debris flows often form elongated deposits, with coarse-grained lateral levees and snouts (Fig. 2b) (e.g., Johnson et al., 2012). Fans or slopes that are dominantly aggraded by debris flows consist of stacked, vertically and laterally amalgamated, elongate, straight to sinuous lobes, which, if not buried by subsequent lobes, are connected to leveed channels (Fig. 2a) (e.g., Johnsson et al., 2014). Local surface relief is generally high in comparison to other fan types, due to relatively thick lateral levees and depositional lobes, and ranges between 0.5 and $4 \mathrm{~m}$ (e.g., Volker et al., 2007; Blair and McPherson, 1998, 2009). Debris flows can flow on slopes as low as a few degrees, but are immobile on lower slopes because the vertical component of gravity needs to overcome the internal yield and frictional strength conferred by fine- and coarse-grained sediment fractions within the flow, respectively (e.g., Major and Iverson, 1999). Debris-flow fan slopes typically decrease from $10^{\circ}$ to $20^{\circ}$ at the apex to $2-5^{\circ}$ at the fan toe, and radial length typically ranges between 0.5 and $10 \mathrm{~km}$ (Fig. 2b) (e.g., Blikra and Nemec, 1998; Blair and McPherson, 2009). However, depositional slopes of unconfined hillslope debris flows can be much higher and often exceed $20^{\circ}$ (Conway, 2010).

Fluvial flows (i.e., hyperconcentrated and stream flows) generally require much larger volumes of liquid water than debris flows (Pierson and Costa, 1987; Pierson, 2005). Their newtonian rheology 


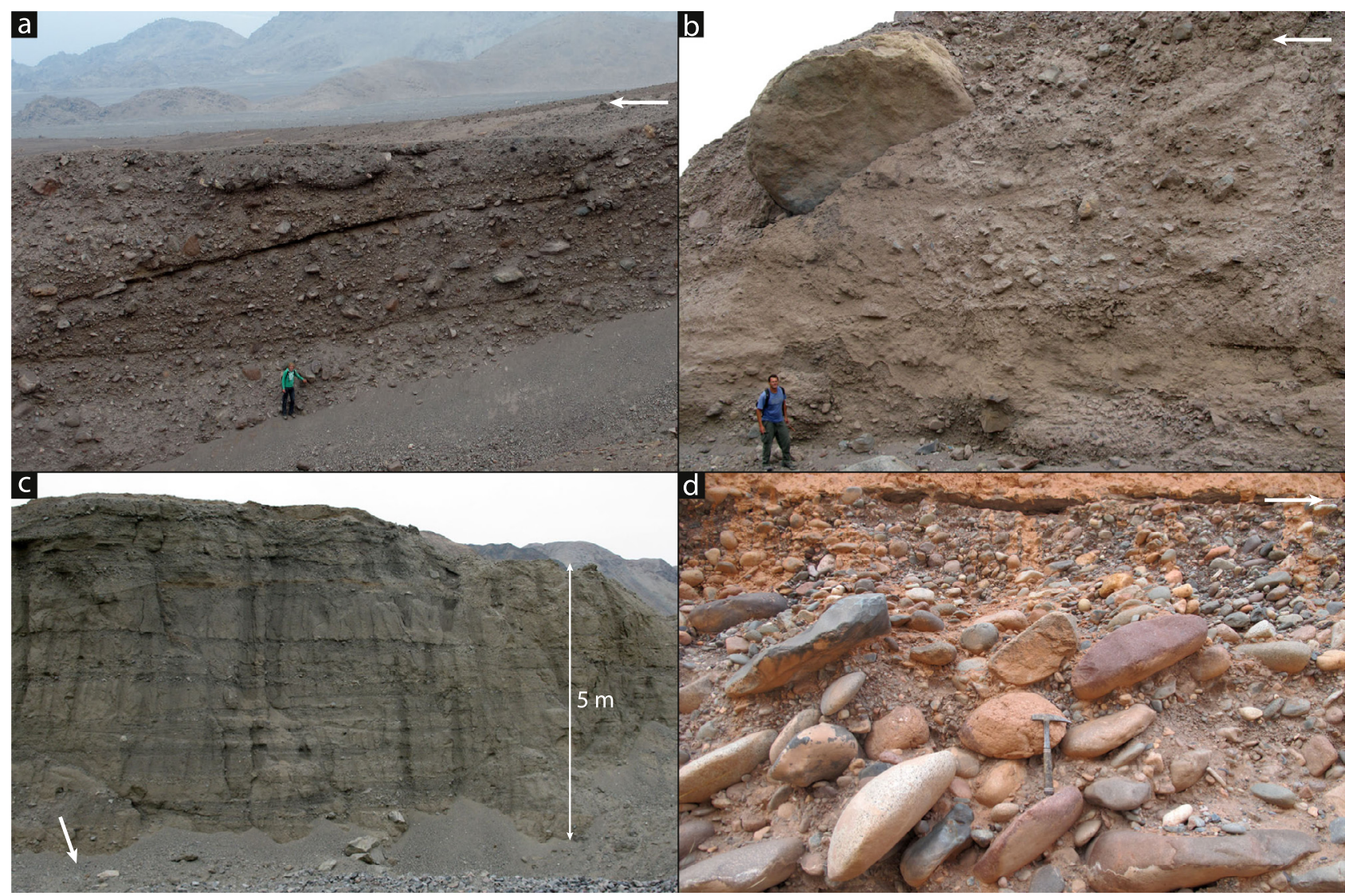

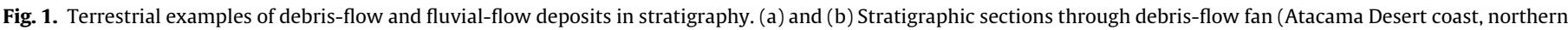

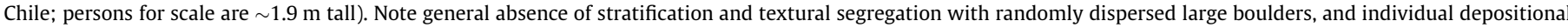

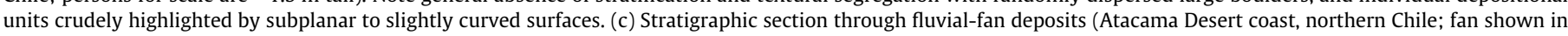

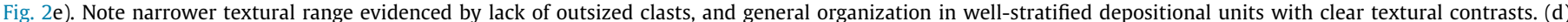

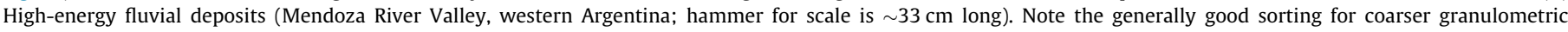
framework and imbricated position of clasts. White arrows in all pictures point to downslope transport direction.

enables flow over very low topographic gradients. Fluvial flows are able to transport only a relatively restricted range of small-sized grains compared to debris flows. As a result, the bulk of sediments transported in fluvial flows commonly ranges in size from clay to fine gravel. Maximum transported clast size is strongly dependent on stream power (which in turn depends upon flow depth, velocity, discharge, slope gradient and hydraulic geometry of the active flow), but typically does not exceed a few decimeters in diameter on relatively steep fans. Sediments entrained by fluvial flows are generally gradually deposited and sorted as flow competence decreases during waning stages, with the coarsest, least mobile fractions deposited first (e.g., Todd, 1996). In stratigraphy, this results in well-organized and sorted deposits, fining-upwards facies succession (because of progressive decrease in flow energy at waning hydrograph stages) and imbricated clasts (clast long axes oriented transverse to flow) (Bluck, 1979; Todd, 1996) (Fig. 1c,d). Depositional architectures can be organized in associations of bedforms (e.g., ripples and dunes) and macroforms (e.g., mid-channel and lateral bars). In planform, deposits are very well structured at a variety of scales from millimetric laminations to metric macroforms (e.g., Collinson, 1970; Miall, 1988; Brierley, 1996; Holbrook, 2001) (Fig. 2c and d). However, the extreme variety of possible runoff phenomena and regimes results in many different types of deposits, ranging from relatively homogeneous, tabular sheetflow deposits to channel fills with complex, braid-like geometry (Fig. 2d). Local relief within individual deposits does generally not exceed a few decimeters (Fig. 2d), although incised channels might locally provide larger relief differences.
Fluvial-flow dominated fans generally have much larger radial lengths $(1->100 \mathrm{~km})$ than debris-flow fans and relatively low slopes $\left(<5^{\circ}\right)$ (Fig. 2c) (e.g., Blikra and Nemec, 1998; Horton and DeCelles, 2001; Wilkinson et al., 2006; Blair and McPherson, 2009).

\section{Materials and methods}

\subsection{Data analyses}

This work is based on the analysis of 51 HiRISE images widely distributed over the southern midlatitudes (Fig. 3), given in Reiss et al. (2011). The resolution of HiRISE images does not allow for fully detailed sedimentological analyses of incised sections; only large boulders $(>0.5 \mathrm{~m})$ and layering patterns can clearly be resolved. As such, the presence or absence, and distribution of boulders and large-scale layering within stratigraphic sections are very important for process interpretation of gully-fans on Mars. Criteria used to evaluate the potential of boulder transport by rockfalls, debris flows and fluvial flows to gully-fans are presented in Section 3.3.

The presence of boulders on gully-fans also depends on catchment lithology. Martian gully-catchments may incise into either bedrock (i.e., original crater wall material) or into the latitude-dependent mantle (LDM), a smooth, often meters-thick deposit consisting mainly of ice and dust, deposited from the poles to midlatitudes during periods of high obliquity (e.g., Mustard et al., 2001), or into a combination of both (e.g., Aston et al., 2011). 


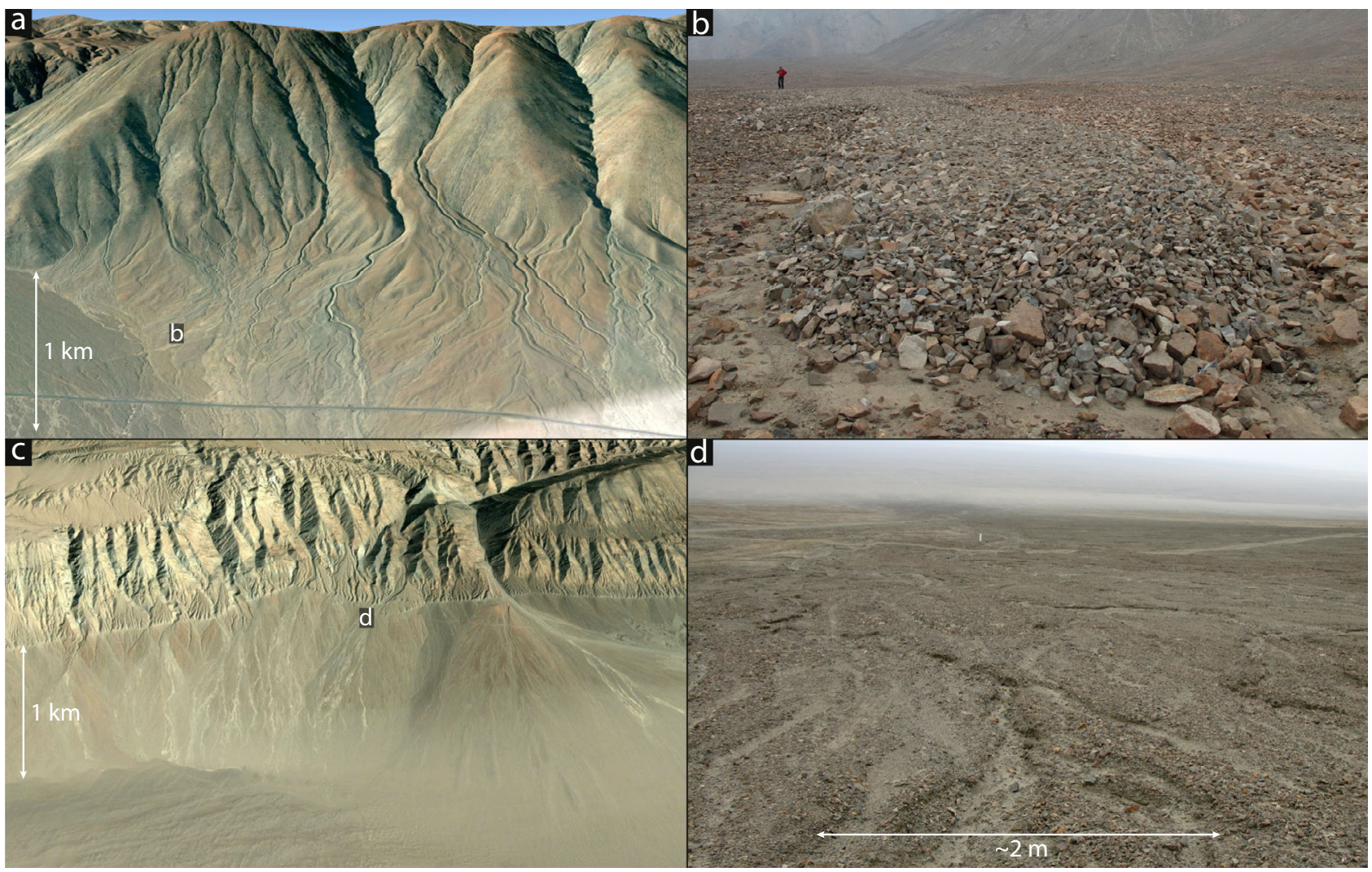

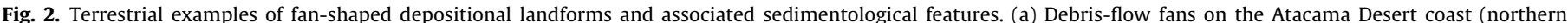

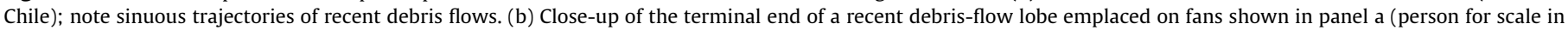
background is $\sim 1.7 \mathrm{~m}$ tall). (c) Runoff-dominated fan surfaces (Atacama Desert, northern Chile). (d) Fluvial-flow deposit on the fans shown in panel c.

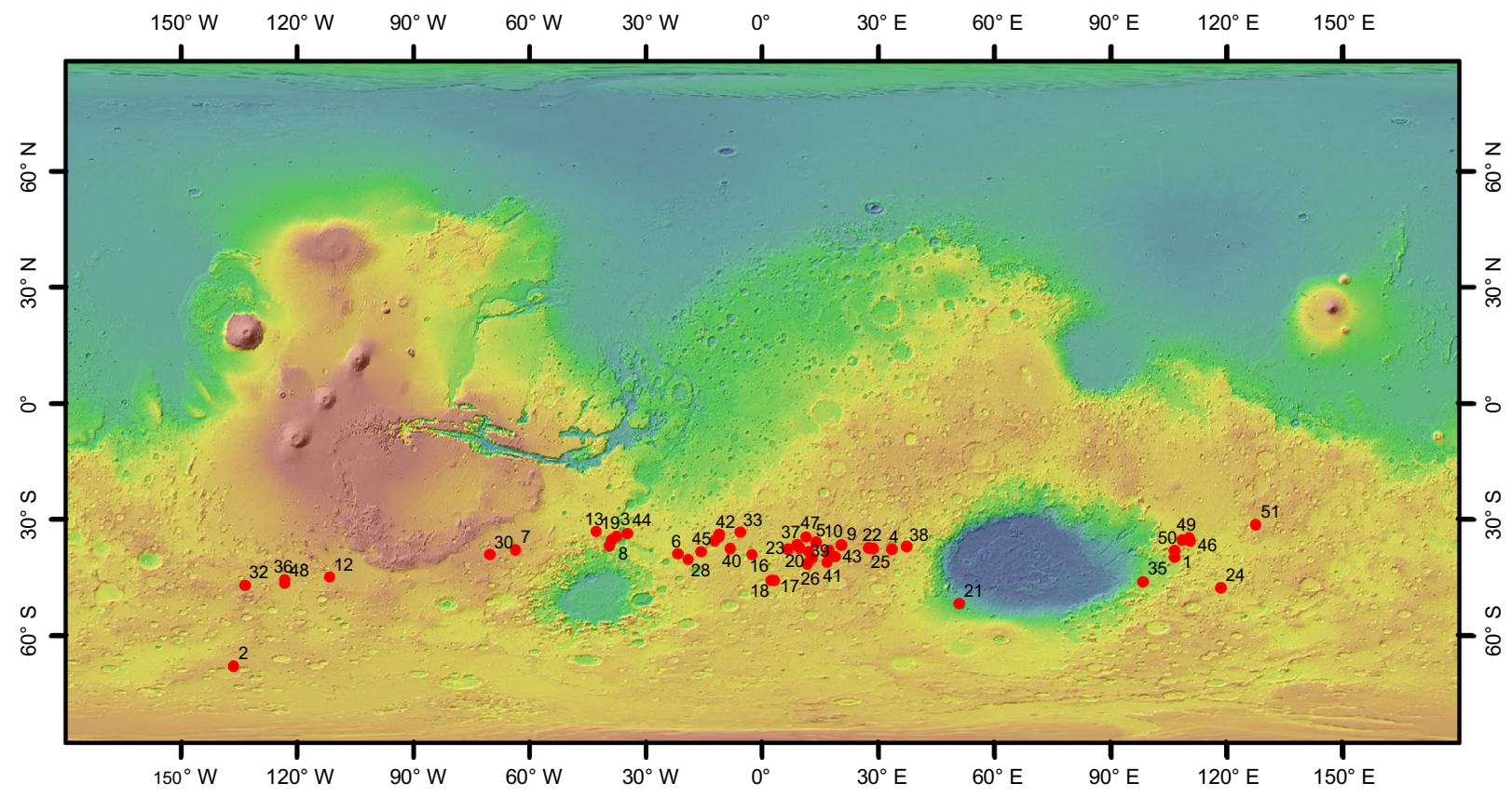

Fig. 3. Location of the studied HiRISE images (Table S1).

In general, gullies that mainly erode into LDM have elongate catchments, whereas gullies cutting into bedrock have more amphitheater- shaped catchments (Levy et al., 2009a) (Fig. 4). As the LDM consists mostly of fine sediments, large boulders will generally be absent in exposures of gullies fed exclusively by the LDM, regardless of the sediment transport processes involved. Therefore, it is important to take catchment lithology into account when using boulders in stratigraphy to infer gully-formative processes. 


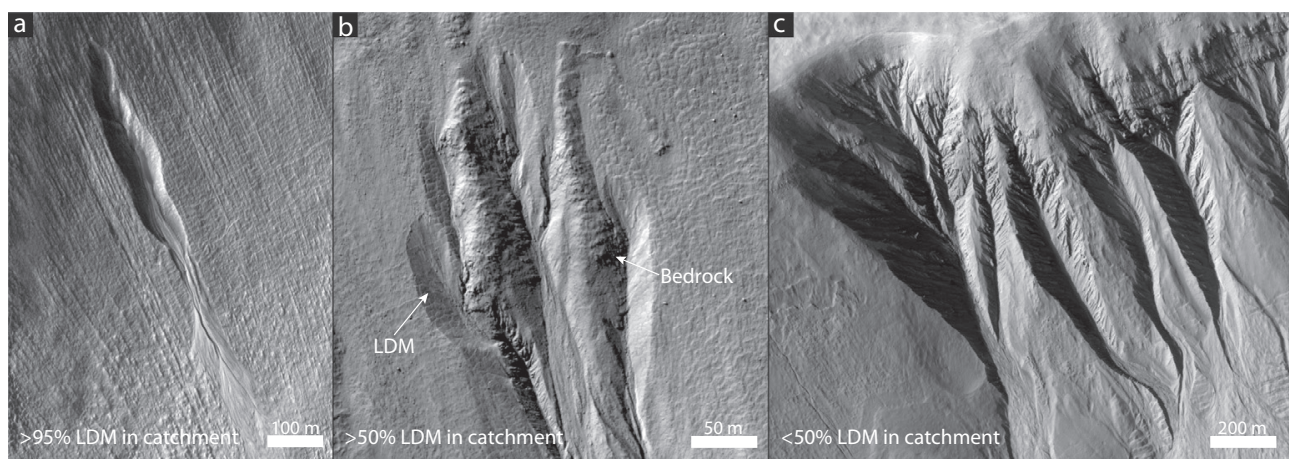

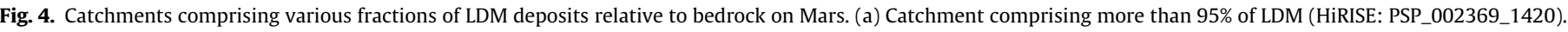
(b) Catchment comprising more than 50\% of LDM (HiRISE: ESP_023809_1415). (c) Catchment comprising less than 50\% of LDM (HiRISE: PSP_003162_1445).

Based on the above, we visually determined for each investigated HiRISE image: (1) if the gullies comprised incised channels exposing stratigraphic sections; (2) if these exposed large boulders ( $>1 \mathrm{~m}$ ) or evidence for layering, and ( 3 ) dominant catchment lithology, focusing on the abundance of LDM deposits. Three categories were visually defined for catchment lithology: (1) catchments that mostly comprise LDM (approximately $>95 \%$ ) by visual estimate, (2) catchments of which more than half consists of LDM (approximately $>50 \%$ and $<95 \%$ ) and ( 3 ) catchments of which less than half comprises LDM (approximately <50\%) (Fig. 4).

\subsection{Production of digital elevation model}

As a detailed example, the morphometry, morphology and stratigraphy of gullies in Galap crater $\left(37.7^{\circ} \mathrm{S}, 192.9^{\circ} \mathrm{E} ; 5.5 \mathrm{~km}\right.$ diameter), are discussed in Section 4.1. To evaluate the morphometry of these gullies, a digital elevation model (DEM) of the crater was constructed from HiRISE stereo images ESP_012549_1420 and PSP_003939_1420 using the methods described by Kirk et al. (2008). The vertical precision of the DEM can be estimated based on viewing geometry and pixel scale. The stereo convergence angle of the HiRISE images is $21.7^{\circ}$, the largest ground pixel size of the two images is $0.291 \mathrm{~m}$, and assuming $1 / 5$ pixel correlations yields a vertical precision of $0.291 / 5 / \tan (21.7)=0.15 \mathrm{~m}$ (Kirk et al., 2008).

\subsection{Evaluation of boulder emplacement mechanisms}

In contrast to fluvial flows and rockfalls, boulder transport by debris flows can occur at all slope angles that are typical for terrestrial and martian fans (e.g., Blair and McPherson, 1994, 2009). In the following, we review the methods to evaluate the potential of boulder transport by fluvial flow and rockfall to assess whether these processes could account for the dislocation of boulders observed on the fans we studied.

Rockfalls transport boulders under the sole effect of gravity, and therefore boulders transported by rockfalls generally halt on relatively steep slopes $\left(>20^{\circ}\right.$ ) (Blikra and Nemec, 1998; Blair and McPherson, 2009). The runout distance of boulders transported by rockfall are often evaluated using the reach angle model or the shadow angle model (Heim, 1932; Evans and Hungr, 1993; Copons et al., 2009). The reach angle model uses the mobility index $H / L$, where $H$ is the vertical fall height (m) and $L$ is the horizontal runout distance $(\mathrm{m})$. The ratio $H / L$ is equivalent to the arctangent of the dipping of the line connecting the rockfall source to its depositional position. Alternatively, the shadow angle is the arctangent of the relationship $H t / L t$, where $H t$ is the vertical fall height on the talus slope, and $L t$ is the horizontal travel distance on the talus slope. On Earth, the reach angle typically ranges between $28^{\circ}$ and $34^{\circ}$, and the shadow angle between $22^{\circ}$ and $30^{\circ}$ (Lied, 1977;
Evans and Hungr, 1993; Wieczorek et al., 2008; Copons et al. 2009; Dorren et al., 2011). In these models, the longer the travel distance, the lower the reach angle and shadow angle. Variations in reach and shadow angle mainly depend on boulder size, angularity and shape, and runout substrate characteristics. Although these simple empirical models are formulated under terrestrial conditions they can probably be used as conservative estimates of rockfall mobility on Mars, i.e., rockfall mobility is probably lower under the smaller gravitational acceleration on Mars although the lower atmospheric density might partly counteract the smaller gravitational acceleration. More qualitatively, on most gullies the rockfall boundary, the lowest gradient on which boulders transported as rockfall can be deposited, can often be determined visually from the HiRISE images by the marked decrease in boulders downslope from this gradient domain.

The mobility of boulders transported by fluvial flows on a given slope can be evaluated by comparing the stress exerted on a clast with the critical stress required to mobilize the clast (e.g., Lamb et al., 2008). We calculate the critical Shields number for incipient motion via the method of Lamb et al. (2008) designed for steep streams, which takes into account slope-specific effects of a non-logarithmic vertical flow velocity profile, grain emergence, aeration of the flow and turbulence fluctuations at the bed (for a detailed description of the equations and assumptions used the reader is referred to Appendix A). Following Prancevic et al. (2014), we add the critical shear stress for bed failure (Takahashi, 1978) to our analysis. When bed Shields stress exceeds the critical Shields stress for bed failure, the entire bed becomes mobile and a debris flow is initiated, which implies that fluvial flows cannot develop above the critical Shields stress for bed failure (Prancevic et al., 2014).

\section{Results}

This section presents morphological and stratigraphic observations on the examined gullies. The gullies in Galap crater are discussed first as a detailed example, describing their stratigraphy, morphology, morphometry, and their interconnection. We chose Galap crater because of the presence of a DEM and large gully-incisions exposing many boulders. Next, general observations on gully-fan stratigraphy and surface morphology are summarized.

\subsection{Stratigraphy, morphometry and morphology of Galap crater gullies}

\subsubsection{Observations}

Galap crater hosts multiple large gullies with fans up to $1.7 \mathrm{~km}$ in length on its pole-facing slopes (Fig. 5a). The catchments of 


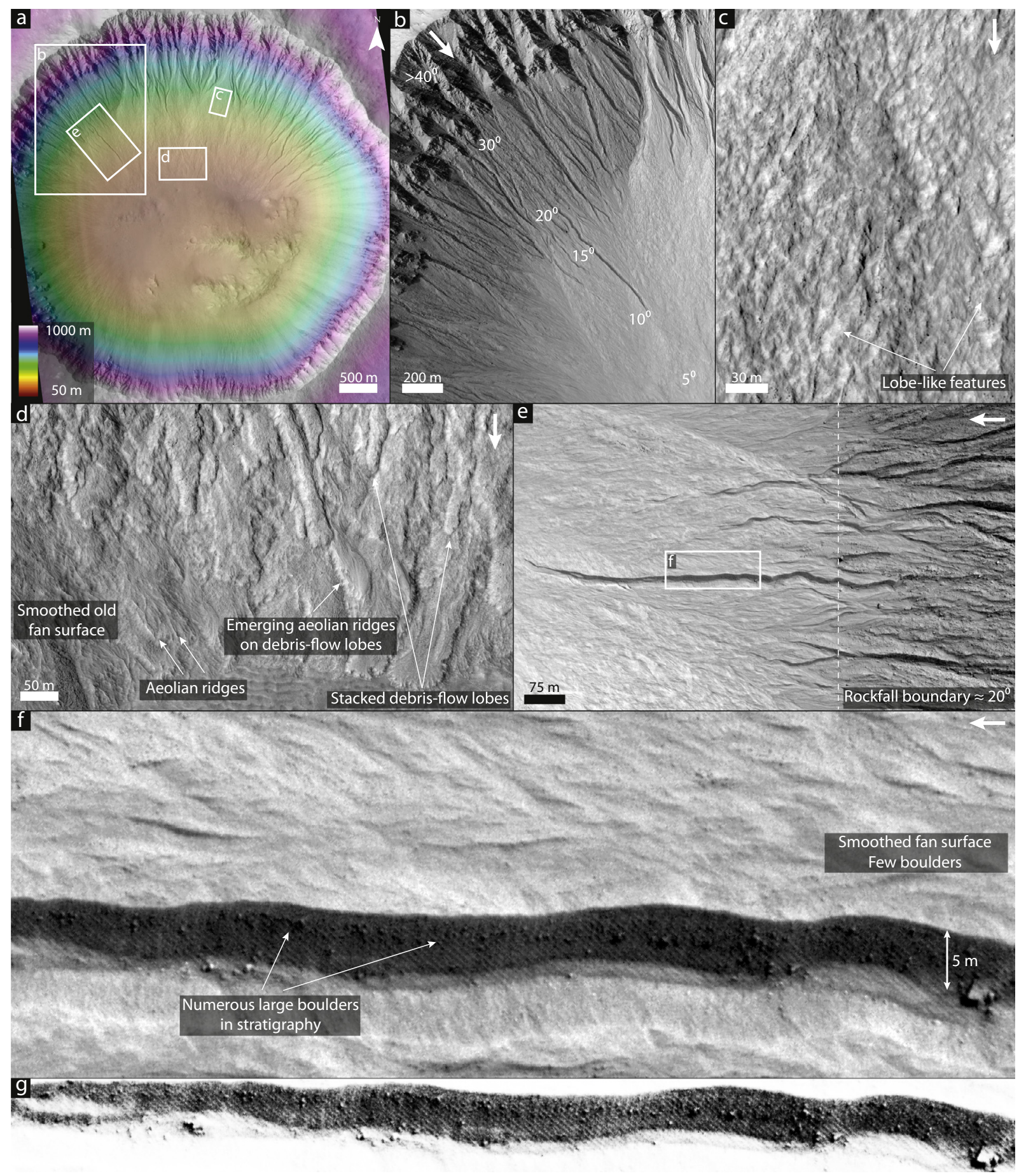

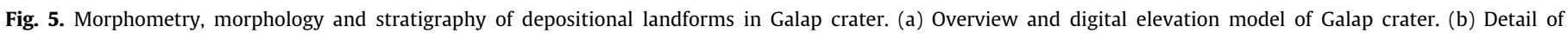

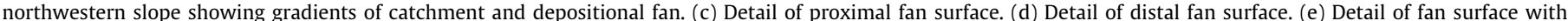

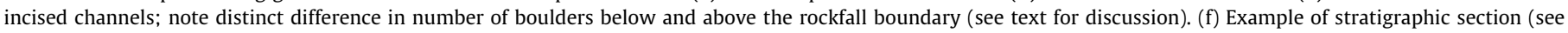

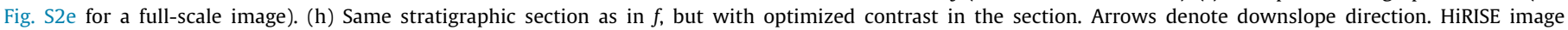
PSP_003939_1420.

these gullies mainly comprise bedrock, and have gradients ranging between $25^{\circ}$ and $42^{\circ}$. The gully-fans have surface gradients between $15^{\circ}$ and $20^{\circ}$ at the apex, down to $5^{\circ}$ at their toe (Fig. 5b). Such slopes are commonly observed on martian gullies; although fan toe gradients are relatively low in Galap crater (gully-fan toe gradients typically range between 5 and $10^{\circ}$ ). Stacked, elongate lobes with distinct relief are recognizable on parts of the distal fan domains (Fig. 5d). Relief differences along the edges of these lobes are sharp and generally range between 1 and $2 \mathrm{~m}$. However, these lobes are discernible only on a very minor fraction of the gully-fan surfaces (Fig. $5 c$ and e). Most of the gully-fan surfaces are composed of irregular, juxtaposed, bar and swale morphology (Fig. 5c and f). These features are relatively smooth and lack distinct relief with sharp edges. Local relief on these surfaces generally does not exceed $0.5-1 \mathrm{~m}$. A few surfaces on distal fan domains adjacent to the stacked lobes are dominated 
by subparallel alignments of sharp-crested ripples and dunes. Similar, but larger dunes occur on the crater floor. Boulders $(>1 \mathrm{~m})$ are scattered throughout the gully-fan surfaces, but not in great numbers and approximately with equal abundance over distal and proximal fan domains, down to slopes of $5^{\circ}$. A marked decrease in boulder abundance is observed on slopes with gradients lower than $\sim 20^{\circ}$ (Fig. 5e). Note that this transition also marks the start of the gully-fan deposits, rather than colluvial slope deposits (Fig. 5b).

Multiple incised channels expose stratigraphic sections along the pole-facing gully-fans (Fig. 5a, b, f, and g). The sections are relatively massive in appearance, but comprise many boulders dispersed within clearly finer sediment (Fig. $5 \mathrm{f}$ and $\mathrm{g}$ ). Boulders, up to $4.5 \mathrm{~m}$ in diameter, are visible at all stratigraphic depths along sections. Their distribution is laterally continuous, but boulder concentrations are recognizable locally. The stratigraphic section in Fig. $5 \mathrm{f}$ has been divided in three lateral sections of equal length ( $\sim 180 \mathrm{~m}$ ), and the diameters of clearly visible boulders have been manually measured (within 1 pixel accuracy: $\sim 0.25 \mathrm{~m}$ ) (Fig. 6). It was possible to measure some boulders down to $0.5 \mathrm{~m}$ in diameter when they were favorably illuminated, but generally only boulders with diameters $>0.75 \mathrm{~m}$ were clearly discernible. The bed gradient is $>15^{\circ}$ in the proximal domain of the section, decreasing to $10^{\circ}$ in the distal domain. Boulder abundance is generally invariant along the section, ranging in number between 75 and 80 within each subsection (note that the real number is higher in all sections, as only diameters of clearly discernible boulders were measured). The median size of boulders decreases only slightly downfan, being $1.2 \mathrm{~m}$ in the proximal domain of the section and $1.1 \mathrm{~m}$ in the medial and distal domain. Maximum boulder size is $4.2 \mathrm{~m}$ in the proximal domain, $2.1 \mathrm{~m}$ in the medial domain and $2.2 \mathrm{~m}$ in the distal domain. Boulder abundance and size are thus approximately similar along the section. This is in good agreement with the gully-fan surface, whereon boulder abundance is generally equal over the proximal and distal domains. However, there is a striking difference in boulder abundance between the stratigraphic section, which clearly exposes many boulders scattered within the sediment, and the directly overlying surface, where only very few large boulders are distinguishable (Fig. 5f).

\subsubsection{Interpretation}

The gradient of the pole-facing gully-fans is similar to the typical gradient of terrestrial debris-flow fans (Blikra and Nemec, 1998; Blair and McPherson, 2009). Moreover, the steep and small catchment size relatively to fan size implies formation by debris flows (e.g., Crosta and Frattini, 2004; Wilford et al., 2004; Welsh and Davies, 2011). The incised channels in the gully-fans might result from debris-flow incision (e.g., Suwa and Okuda, 1983) or fluvial runoff, which incises the fan surface but does not significantly contribute to fan aggradation (e.g., Blair and McPherson, 1994, 2009). General sedimentological traits in the stratigraphic sections along incised channels are also typical for debris-flow deposits. The great abundance of boulders exceeding $1 \mathrm{~m}$ in diameter on slopes down to $10^{\circ}$ match with the characteristics of debris-flow deposits (Blikra and Nemec, 1998; Blair, 1999). Moreover, boulders in the studied sections appear dispersed within finer sediments and are thus matrix-supported, as common in debris-flow deposits, whereas tractive transport in fluvial flows generally results in clast-supported, better sorted deposits in which coarse clasts are in mutual contact (e.g., Bluck, 1979; Todd, 1996). Finally, the nearly equal abundance and size of boulders from proximal to distal domains along the section in Fig. 6 implies emplacement by debris flows, as fluvial deposits typically fine downstream, because of the gradual decrease in competence from higher to lower gradients.

The deposits on the walls of Galap crater show a marked decrease in boulder abundance at a gradient $<20^{\circ}$ (Fig. 5e), interpreted here as the boundary above which boulders can be emplaced by rockfall. In contrast, debris flows can transport boulders down to slopes of a few degrees and can therefore not explain this sharp boundary in boulder abundance. This interpretation is further supported by a reach angle of $28^{\circ}$ and a shadow angle of $22^{\circ}$, similar to the lower boundaries of the reach angle and shadow angle observed on Earth. The investigated stratigraphic section extends along gradients down to $10^{\circ}$, far below the angle of repose. Moreover, the reach angle $\left(23^{\circ}\right)$ and shadow angle $\left(19^{\circ}\right)$ are below the lowest values possible for rockfall emplacement. As such, transport of boulders to the stratigraphic section by rockfalls can probably be excluded. This inference is further supported by the
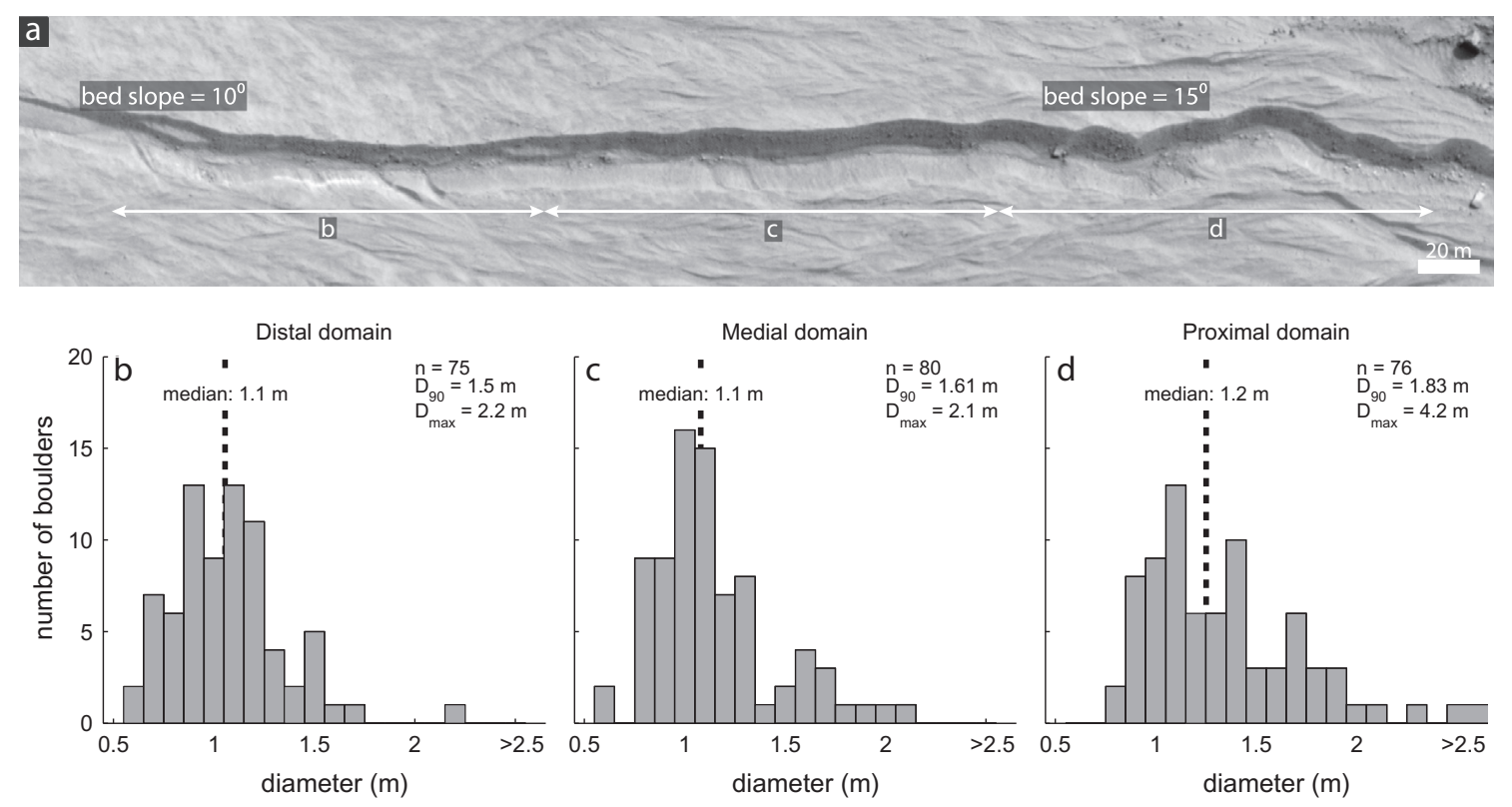

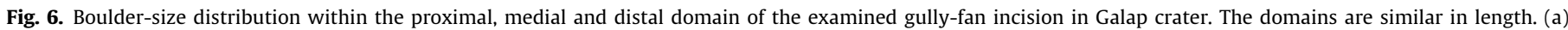

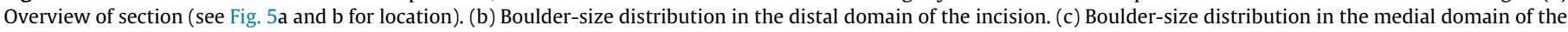
incision. (d) Boulder-size distribution in the proximal domain of the incision. 
marked morphometric, morphological and textural contrast with the depositional aprons on slopes with non-polar azimuths in Galap crater, which have slopes, radial lengths, morphological and textural characteristics typical of accumulation by rockfalls and grainflows (e.g., very steep fans, near the angle of repose, with short radial lengths, a downslope coarsening texture and topographically smooth surfaces; Blikra and Nemec, 1998; Blair and McPherson, 2009; Ventra et al., 2013).

Deposition by fluvial runoff on fans occurs generally as sheetfloods (Blair and McPherson, 2009), which are short-duration, catastrophic floods of unconfined water (Bull, 1972) that develop when confined runoff from the catchment expands over the fan surface. Fig. 7 shows the mobility of boulders of $1 \mathrm{~m}$ and $2 \mathrm{~m}$ in diameter in sheetfloods on a range of slopes under martian conditions (Section 3.3). For the investigated stratigraphic section in Galap crater, sheetflood depths of almost $4 \mathrm{~m}$ are required for the transport of $1 \mathrm{~m}$ diameter boulders on a slope of $10^{\circ}$ (Fig. 7), while sheetflood depths of almost $8 \mathrm{~m}$ are needed to transport boulders of $2 \mathrm{~m}$ in diameter. Given the unconfined nature of sheetfloods, flow depths rarely exceed $1 \mathrm{~m}$ due to lateral expansion over the fan (e.g., Blair and McPherson, 2009), and considering the relatively small size of gully-catchments on Mars, boulder deposition by fluvial flows is practically to be excluded. Moreover, the catchments in Galap crater in the vicinity of the investigated stratigraphic section are proximally connected to relatively steep slopes ranging in slope from $>30^{\circ}$ down to $\sim 20^{\circ}$ (Fig. 5b). In case of sheetflood sufficiently competent to transport boulders, waterflow over such steep slopes would exceed the critical Shields stress for bed failure and mobilize the regolith leading to debris flow (Fig. 7) (Prancevic et al., 2014).

Despite the morphometric and stratigraphical evidence for debris flows, stacked, elongate lobes with distinct relief are present only on the distal fan domains (Fig. 5d), but absent on most of the gully-fan surfaces. Leveed channels have not been recognized on the gully-fan surfaces. The marked contrast between the great number of boulders recognizable from stratigraphic sections and their scarcity on the surface suggests that many clasts exposed over gully-fan surfaces may have been disintegrated by weathering and abrasion. The abundance of boulders on steeper slopes is caused by the continuous input by rockfalls, whereas there has been no boulder input to the gully-fans since the last period of gully-fan activity. The potential for secondary reworking by wind erosion is testified by the presence of dunes on crater floors, and incipient dunes on distal parts of the gully-fan surfaces.

In short, the gradients and stratigraphy of gullies on the pole-facing slopes of Galap crater expose strong evidence for sediment transport by debris-flows, whereas the vast majority of surfaces lack clear morphological evidence for debris-flows, suggesting secondary reworking by weathering and erosion. Later we will show that this is representative for many of the other investigated gullies. Observations and interpretations on the stratigraphy and morphology of these gullies are summarized below.

\subsection{Stratigraphic observations and interpretation}

Of the 51 investigated HiRISE images with gullies, 44 show one or more deep, laterally continuous, incised sections along channels in the depositional fans (Fig. 8a-d). Of these sections, 57\% bear clear sedimentological evidence of dominant aggradation by debris flows, by the presence of large boulders and/or subparrallel layering with lens-shaped to truncated units (Fig. 9a; Table S1). Sediment in these outcrops is very heterogeneous in texture, comprising many large boulders, some of which exceed $3 \mathrm{~m}$ in diameter, randomly dispersed within finer debris. Although we do not have DEMs for many of these gullies, general observations on gully-fan slopes imply that the vast majority of gullies have gradients similar to those of gully-fans in Galap crater (e.g., Heldmann and Mellon, 2004; Dickson et al., 2007; Levy et al., 2010; Conway et al., 2011, 2015). Fluvial transport of such large, isolated boulders along the investigated gullies is thus highly unlikely. Moreover, the analysis excluded stratigraphic sections extending above the rockfall boundary, as previously defined, as well as outcrops in the vicinity of steep bedrock relief. As such, the boulders in the analyzed sections were probably not transported by rockfalls or grainflows. Boulder alignments have been observed locally in stratigraphic sections, with orientations roughly parallel to the main fan surface indicating possible coarse-clast segregation at the margins of debris-flow lobes (Figs. $5 \mathrm{f}$ and $\mathrm{g}$ and $8 \mathrm{a}-\mathrm{d}$ ). Deposits generally appear massive, but a crude, subparallel layering is visible along several incisions (Figs. 8 and 9b), with strata varying in geometry from tabular and continuous downslope to lens-shaped and locally truncated units (Fig. 8d). Recognizable layers range in thickness from 1 to $5 \mathrm{~m}$. The combination of textural heterogeneity, outsized clasts, and crude tabular bedding extending along visible outcrops is typical for debris-flow deposits (Blikra and Nemec, 1998; Blair and McPherson, 1998; Blair, 1999). The massive appearance of most sections is likely the result of stacked depositional units with poor sorting and lack of internal structure (e.g., Major, 1997; Blair, 1999). The very poor sorting of deposits and the occurrence of very coarse material dispersed in a finer matrix result from rapid halting of dense sediment mixtures in which high viscosity and particle interlocking prevent the spatial segregation of debris according to grain sizes (Pierson and Costa, 1987;
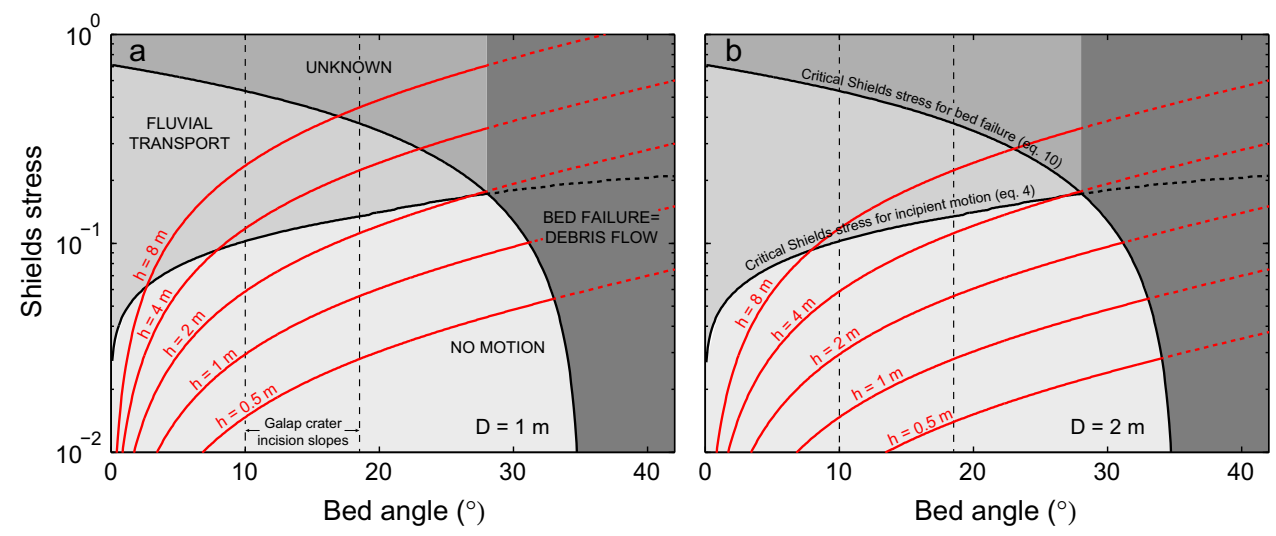

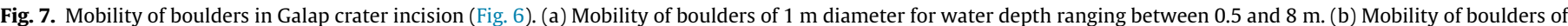

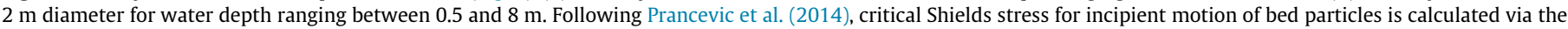
method of Lamb et al. (2008) and critical Shields stress for bed failure is calculated via the method of Takahashi (1978) (see Appendix A). 


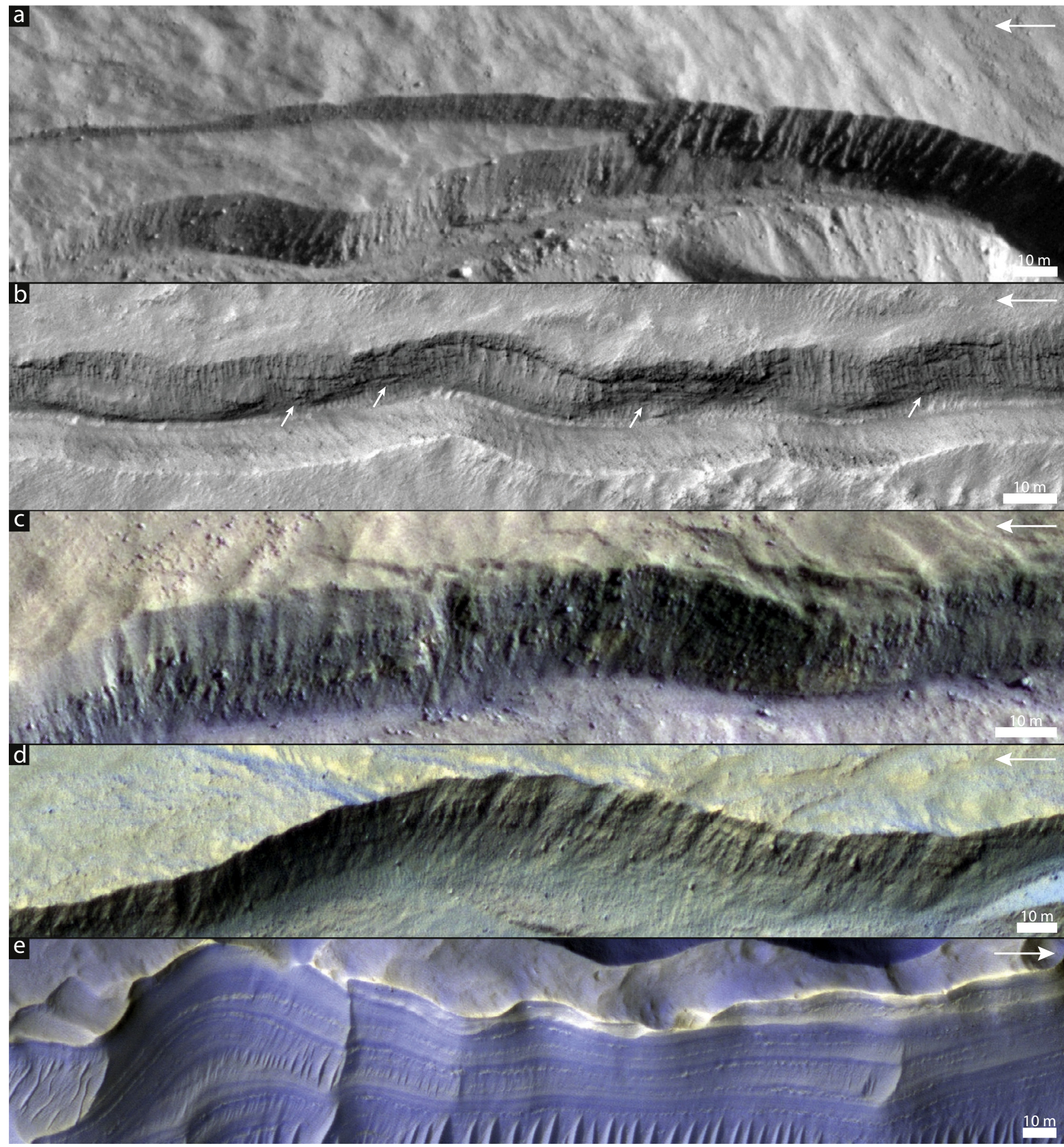

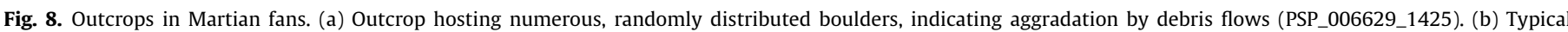

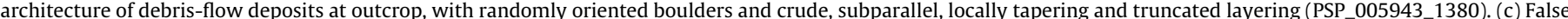

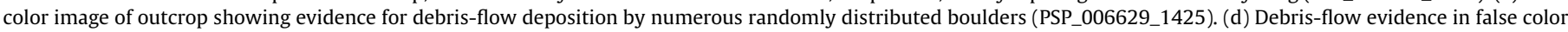

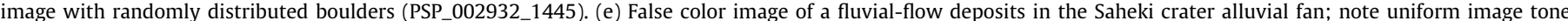

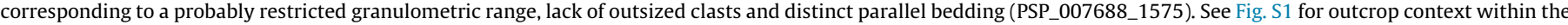

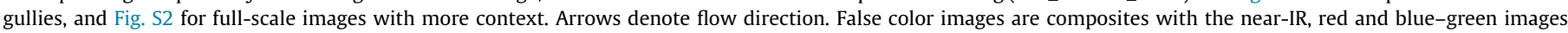

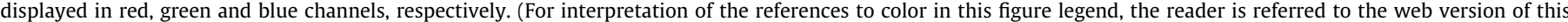
article.)

Iverson, 1997; Blair and McPherson, 1998). The apparent subvertical orientation of some boulders is a strong indication of such flow dynamics (e.g., Scott et al., 1995; Blikra and Nemec, 1998; Blair, 2003), in contrast to the horizontal or imbricated coarse-clast orientations typical of deposition from fluvial flows. The continuous, tabular geometry of most depositional units is also characteristic of deposition by debris flows (e.g., Blair, 1999, 2003). The lensoidal shape and sharp terminations of some of these units probably correspond to the high-relief, frontal or lateral margins typical of debris-flow lobes. These sedimentological traits recognizable in gully-fan outcrops stand in marked contrast with deposits of fluvial origin in outcrops along the large alluvial fan in Saheki crater (Fig. 8e) (Morgan et al., 2014), which are massive in appearance, contain no or very few boulders visible at HiRISE resolution, and 
(A) Outcrop characteristics: boulders

(B) Outcrop characteristics: layering
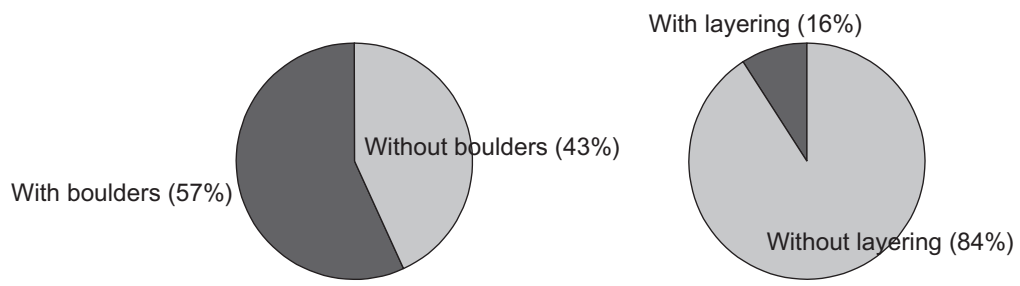

(C) Catchment characteristics of outcrops with boulders

(D) Catchment characteristics of

(E) Catchment characteristics of outcrops with boulders outcrops with layering outcrops without boulders/layering
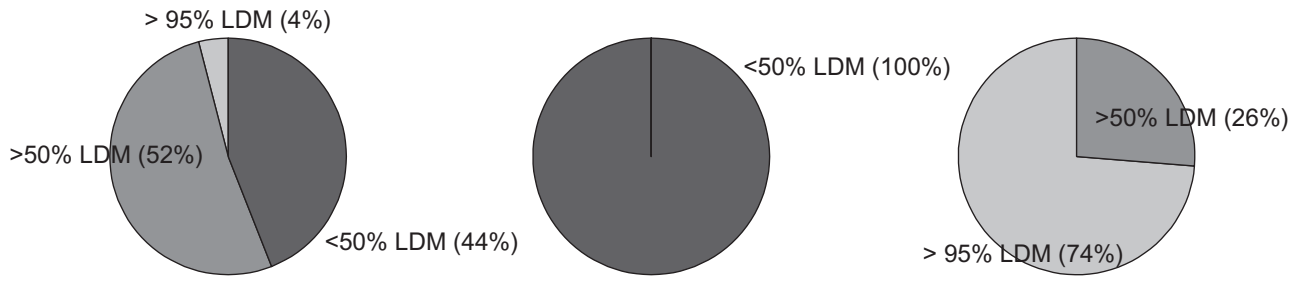

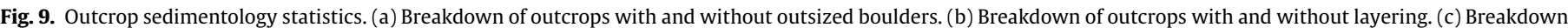

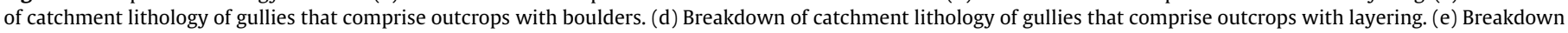
of catchment lithology of gullies that do not comprise outcrops with boulders or layering.

feature the uniformly subhorizontal, thin stratification typical of fluvial-flow deposits, in agreement with the morphometric characteristics of this system.

The great majority (96\%) of fans with typical debris-flow sedimentology, as described above, are fed by catchments that comprise bedrock exposures (Fig. 9c). Lens-shaped and truncated layering is evident only in outcrops of gully-fans fed by catchments comprising $<50 \%$ of LDM. In contrast, the majority of fans lacking boulders are fed by catchments comprising only the LDM (74\%), and the remainder by catchments that comprise more than $50 \%$ LDM (26\%) (Fig. 9e). Consequently, boulders are very rare in these gullies and not recognizable in outcrops, regardless of the dominant transport process. These numbers suggest that the majority of fans lacking debris-flow evidence at outcrop may have formed by fine-grained debris flows, although an origin by fluvial flows cannot be excluded.

\subsection{Morphological observations and interpretation}

A vast majority of studied gully-fan surfaces show evidence of heavy modification by secondary, post-depositional processes. Although sedimentological analysis indicates that many of these investigated gullies were dominantly formed by debris flows, corresponding surface features including pristine paired levees together with depositional lobes occur only in Hale crater out of the 51 investigated HiRISE images (see Fig. 9 in Reiss et al., 2011). On a few other fans, modified stacked depositional lobes are still faintly evident on the most active domains, most likely as last remnants of the original surface morphology (Fig. 5c). On many fans within our dataset young depositional lobes (as inferred from cross-cutting relations) host many more boulders than older ones (Fig. 10d), and there generally is a marked difference between the amount of boulders observed within the outcrops and on the adjacent fan surfaces, which comprise far less boulders (Figs. 5e and 8), similar to long inactive fan surfaces on Earth (Fig. 11) (e.g., Wells et al., 1987; Al-Farraj and Harvey, 2000; Frankel and Dolan, 2007; De Haas et al., 2014). As such, gully-fan lobes of different ages generally show notable differences in morphology and texture as surface smoothness increases and boulder abundance decreases with age (Fig. 10d). In analogy to terrestrial fans, this suggests that surface weathering is common on gully-fans (De Haas et al., 2013), but might alternatively reflect an increasing abundance of crater-wall material versus LDM deposits as the gully evolves for some gullies (note that Galap crater appears to be free of LDM, so the later possibility does not apply to this crater).

Wind erosion is probably the main mechanism of secondary modification on the investigated gully-fans. The original morphology of the fans often appears to be reworked into associations of ridges with sharp, narrow, subparallel crests (Fig. 10a-c), analogous in shape and spatial pattern to aeolian bedforms, such as ripples and small dunes. The orientation of these bedforms is likely transverse to the direction of dominant local winds. The sharp crests probably formed by continuous abrasion by wind, similar to the formation of the sharp crest on ventifacts or yardangs. Moreover, on fans where these ridges are present, small to large dune fields are present on the crater floor. On some of the fans sand sheets and dunes appear to have migrated from the crater floor onto the gully-fan. There are often discernible differences in the presence of aeolian ridges and dunes on gully-fan surfaces of apparently similar age within the same crater, suggesting that the degree of fan-surface modification by wind does not only depend on age, but also on fan location and orientation relative to the dominant wind direction. Additionally, it probably also depends on the availability of fine sediments. The above described fan surface modifications by wind have also been observed on many semiarid to arid region terrestrial fans (Fig. 11d-f) (e.g., Anderson and Anderson, 1990; Pelletier, 2007; Blair and McPherson, 2009). Furthermore, aeolian fines might accelerate mechanical fragmentation of surficial sediments, by wetting and drying of fines in cracks, and might accumulate slowly below the surface during the process of desert pavement development (e.g., McFadden et al., 1987). On some gully-fans deflation selectively winnowed fine, more erodible sediments and left behind coarser lags (Fig. 10e and f), enhancing the primary depositional relief, where coarse sediments are concentrated in relatively elevated remnants of debris-flow lobes and levees. The process is essentially similar to the formation of inverted channels, which are widespread on large alluvial fans on Mars (e.g., Pain et al., 2007; Morgan et al., 2014).

Some fans or parts of fan surfaces host polygonal ground patterns. These can both pre-date and post-date gully activity (Levy et al., 2009a). Moreover, some fans or fan lobes within our dataset are covered by LDM deposits (Fig. $10 \mathrm{~g}$ and h). On such fans, the primary morphology is completely masked by the LDM mantle. This 

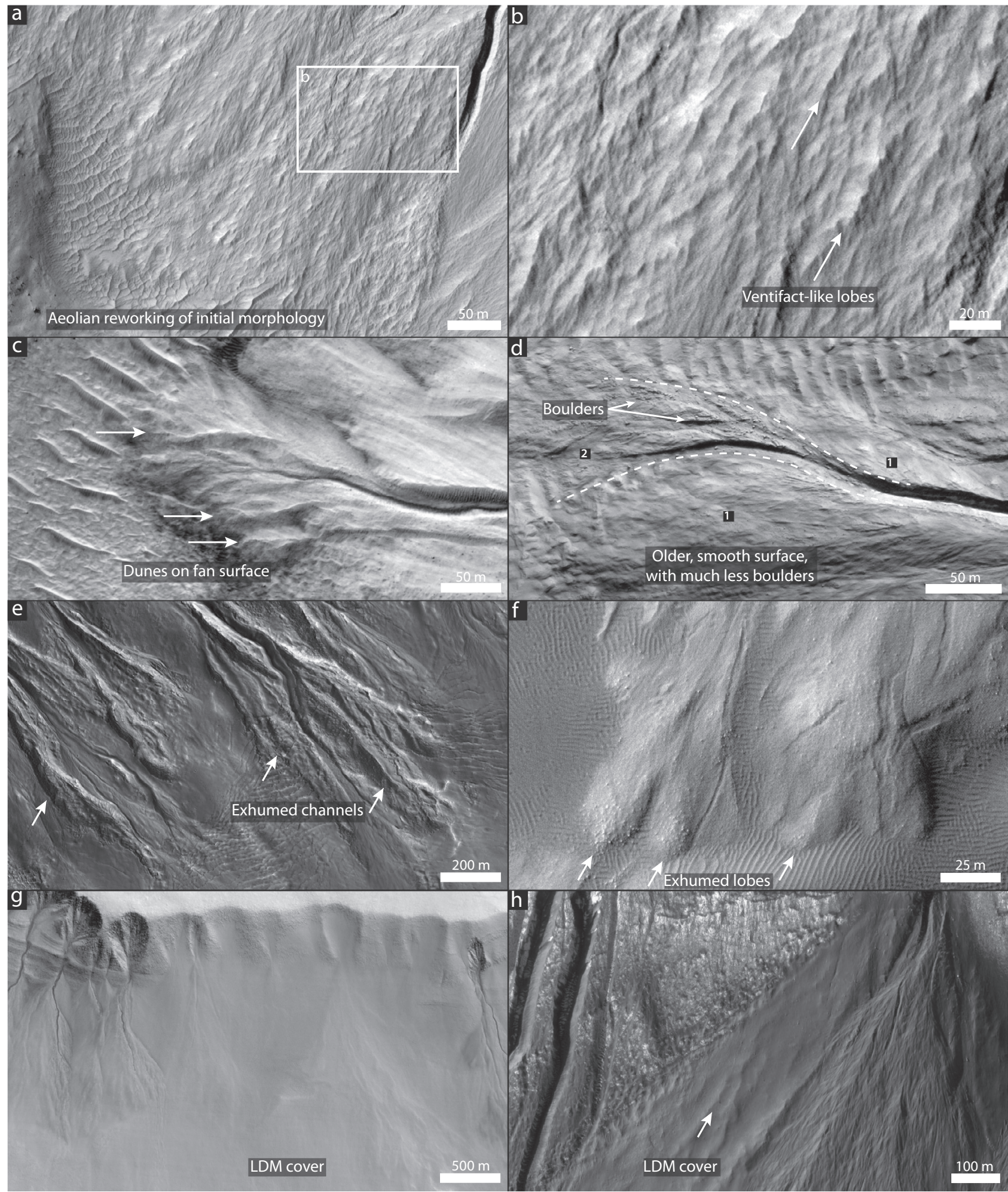

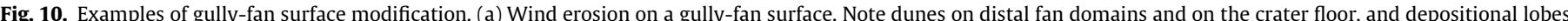

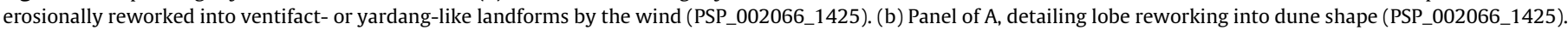

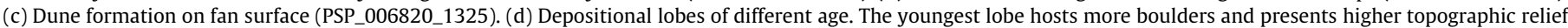

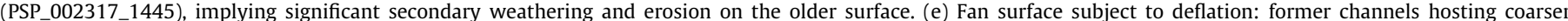

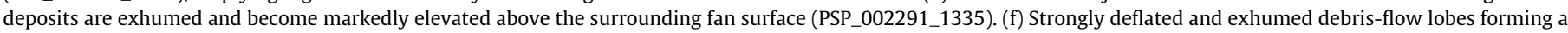

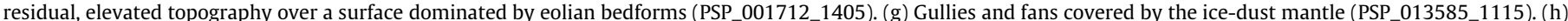
Fan with lobes of different generation, of which the oldest is strongly smoothed and masked by an LDM cover (PSP_001684_1410). See Fig. S3 for full-scale images.

may have led to a complex interaction, with ice-dust mantles acting as debris sources for new gully formation, while potentially masking older gully morphology. Evidence for recent dry flows, evident from a marked color contrast with their surroundings, were only found in a few gullies. They affect a spatially restricted area and their effect on secondary modification is thus considered 


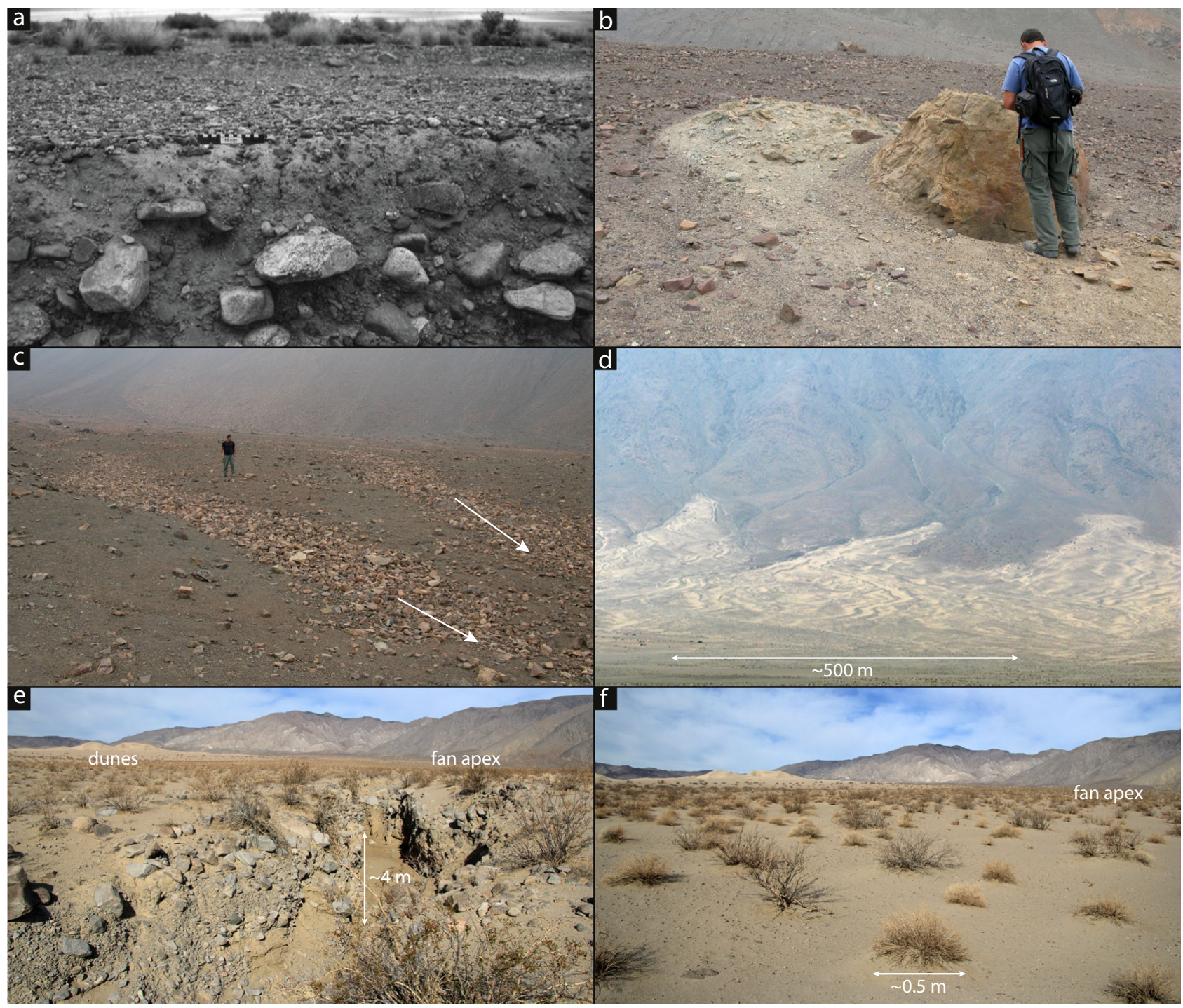

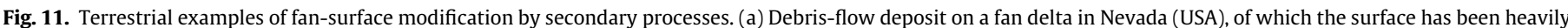

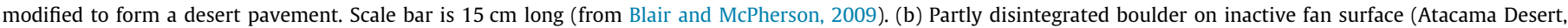

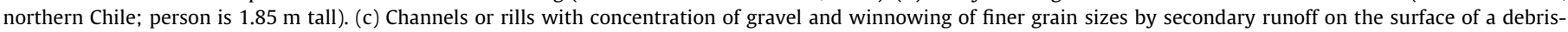

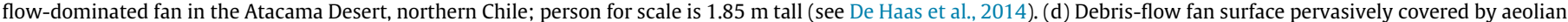

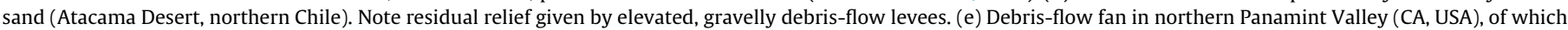

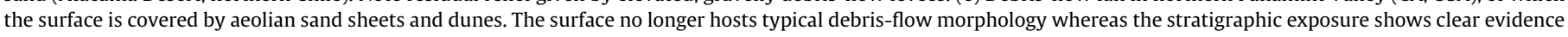
of debris-flow formation. (f) Different perspective of the sand covered debris-flow fan surface in northern Panamint Valley shown in panel e.

minor compared to, for example, the effects of wind erosion, weathering and ice-dust mantling.

Well-developed rills or gullies (Fig. 11c), which typically emerge in case of secondary erosion by overland flows (either locally derived or derived from the catchments) (e.g., Blair and McPherson, 2009), have not been observed on any landforms within our dataset. Nevertheless, some restricted overland flow might have occurred on gully-fans but the overall morphology indicates that the relative effectiveness of wind erosion is significantly greater than that of runoff.

\section{Discussion}

Combined observations of outcrop sedimentology and surface morphology suggest that the majority of gully-fans on Mars dominantly formed by debris-flow deposition, and that typical debris-flow features are strongly modified or erased from fan surfaces by various post-depositional processes. This implies that the relative contribution of debris flows to gully development and fan aggradation has previously been significantly underestimated. This hypothesis explains the discrepancy between morphometric analyses that imply gully formation by debris flows (e.g., Lanza et al., 2010; Mangold et al., 2010; Conway et al., 2011) and frequent observations of fan surfaces lacking clear debris-flow morphology, implying formation by fluvial flows (e.g., Dickson and Head, 2009; Levy et al., 2010; Reiss et al., 2011). These considerations also highlight that interpretation of primary processes based on surface characteristics only can be misleading for long-inactive martian depositional landforms.

The inferred dominant debris-flow origin for most martian gully-fans implies that the volume of available liquid water during gully formation was relatively small and ephemeral compared to formation by fluvial flows (De Haas et al., 2015b). This is in better accordance with the current understanding of recent martian environmental conditions (Hecht, 2002) than an origin by fluvial flows, which would require greater volumes of liquid water over longer time periods (Kleinhans, 2005). During phases of high-obliquity, 
the amount of snow deposited on mid-latitude regions was relatively restricted and hypothesized to be in the order of centimeters per martian year (e.g., Madeleine et al., 2009, 2014; De Haas et al., $2015 b)$. Only a very small fraction of this snow cover is thought to melt into liquid runoff, as most of its volume sublimated (Williams et al., 2009). Gully-catchment lithology and the periglacial conditions on Mars form an ideal precondition for triggering debris flows. Debris flows are easily generated in catchments that yield large volumes of fine sediment (mostly clay and silt fractions) (e.g., Blair, 1999; Harvey, 2010). The catchment lithology of the studied gullies is thus ideal for the formation of debris flows, as it often partly comprises fine-grained LDM deposits. In permafrost environments, such as Mars, debris flows can be triggered by very small amounts of water, as the frozen permafrost table acts as a shallow-subsurface aquiclude favoring excess pore-water pressure development in the active layer and providing a failure plane for regolith mobilization and debris-flow initiation (e.g., Caine, 1980). Moreover, dry areas lacking vegetation such as Mars are relatively susceptible to debris-flow formation via mass wasting events (e.g., Dorn, 1994).

The young age of many martian gullies (Reiss et al., 2004; Schon et al., 2009; Johnsson et al., 2014) and the heavily modified surfaces of most gully-fans suggest that secondary processes of surface modification are relatively brisk and efficient on Mars. The marked difference in abundance between the numerous boulders in many stratigraphic sections and their scarcity or absence on adjacent overlying fan surfaces, and between many fan surfaces of different generation and age, testify to pervasive surface weathering. This is in agreement with observations on late Amazonian weathering and erosion rates. On a gully-fan surface in eastern Promethei Terra, De Haas et al. (2013) found that boulders $>3 \mathrm{~m}$ shattered into fragments $<0.5 \mathrm{~m}$ within $1 \mathrm{My}$. Moreover, De Haas et al. (2013) found that the fan surface relief was smoothed by $\sim 1 \mathrm{~m}$ within the same time period, in good agreement with the complete absence of debris-flow levees and lobes on most martian gully-fans. Similarly, recent erosion rates of small craters, ejecta blocks, sand ripples and dunes, and layered deposits range between 1 and $10 \mathrm{~m} / \mathrm{My}$ (Malin and Edgett, 2000; McEwen et al., 2005; Golombek et al., 2010, 2014; Bridges et al., 2012a; Grindrod and Warner, 2014). The last high-obliquity period $\left(>30^{\circ}\right)$ wherein aqueous gullies were thought to be active ended 0.4 Ma (e.g., Dickson and Head, 2009), and therefore melting and fan aggradation by primary processes involving liquid water did probably not occur since $0.4 \mathrm{Ma}$. As such, the secondary weathering and denudation rates have been sufficiently fast to modify many gully-fan surfaces. This is especially true because weathering and erosion rates greatly decrease with age, as they are gradient-driven and therefore highest shortly after cessation of active depositional processes (De Haas et al., 2013; Golombek et al., 2014). Similarly, alluvial-fan surfaces in Death Valley on Earth were found to be severely modified by secondary processes within a few thousand years, whereas complete smoothing and the development of mature desert pavement took $\sim 70 \mathrm{ka}$ (Frankel and Dolan, 2007).

Secondary processes of surface modification typically active on Earth (e.g., Blair and McPherson, 2009; Harvey, 2011; De Haas et al., 2014), such as wind erosion, weathering and the formation of patterned ground, have probably also modified gully-fan surfaces on Mars. Surficial observations suggest that wind erosion is the most important secondary process on the investigated gully-fans. This agrees with recent observations indicating that erosion of fine sediments by wind is widespread under the current atmospheric conditions on Mars (e.g., Geissler et al., 2010; Bridges et al., 2012a,b; Golombek et al., 2014). Conversely, runoff is more common on Earth, owing to a more active hydrological cycle. Patterned grounds, including polygons and slope stripes, are wide- spread in high-latitude ground-ice regions on Mars (poleward of $\sim 55^{\circ}$ ) (e.g., Mangold et al., 2004; Mangold, 2005), and covers the primary morphology of many gullies in these regions. Such features are also common on inactive surfaces of terrestrial fans in periglacial environments (De Haas et al., 2015a). Surface masking by ice-dust mantles and surface modification by dry flows driven by $\mathrm{CO}_{2}$ ice are processes specific for Mars. Gullies are generally found between $30^{\circ}$ and $60^{\circ} \mathrm{N}$ and $\mathrm{S}$ (Balme et al., 2006; Dickson et al., 2007; Kneissl et al., 2010), whereas the ice-dust mantle is deposited from polar latitudes down to $30^{\circ} \mathrm{N}$ and $\mathrm{S}$ (Mustard et al., 2001; Milliken et al., 2003). Both are formed and emplaced during glacial periods at high obliquity (e.g., Head et al., 2003; Dickson and Head, 2009). Therefore, gullies that predate the latest ice-dust mantling episode are probably covered by these LDM deposits. The relatively high frequency of dry flows in some gullies on Mars (Dundas et al., 2010, 2014), suggests that these flows might be an effective process of secondary modification at certain locations (Dundas et al., 2014). However, we found very little evidence for secondary modification by dry flows, potentially because these deposits are hard to distinguish in the absence of a marked color or tonal difference with older deposits.

Consideration of dry $\mathrm{CO}_{2}$ frost-driven flows as a mechanism of primary aggradation has been excluded from our analyses for lack of a terrestrial analog. As such, we cannot quantify the relative contribution to gully formation by these flows. However, we estimate the contribution of such flows to the formation of most gully-fans to have been relatively small. There is no direct evidence that the majority of gullies was primary formed by dry flows (e.g., Yue et al., 2014), because of the scarcity or even complete absence of gullies in equatorial regions on Mars (e.g., Balme et al., 2006; Dickson et al., 2007), the frequent occurrence of gullies on slopes well below the angle of repose (e.g., Dickson et al., 2007), morphometric characteristics typical for aqueous flows (e.g., Conway et al., 2011; Yue et al., 2014), and strong morphological similarity to terrestrial debris flows in some gullies (e.g., Levy et al., 2010; Johnsson et al., 2014). Moreover, evidence for recent dry flows has been found only in a few tens of gullies, of which most are dune gullies, out of thousands of gullies present on Mars (Diniega et al., 2010; Dundas et al., 2010, 2014). Of course, not every gully has been monitored, but the available dataset is also biased as the sites selected for intensive monitoring were mostly chosen on the basis of previously observed changes, in order to maximize the probability to observe additional activity (Dundas et al., 2012). No terrestrial analog is known for dry $\mathrm{CO}_{2}$-driven flows, and therefore little is known on the morphology and corresponding sedimentology of deposits. To date there are no quantitative or experimental analog models to test the viability of $\mathrm{CO}_{2}$-driven dry flows, let alone to estimate their deposit sedimentology. Quantitative models evaluating the energetic release of sublimating $\mathrm{CO}_{2}$ suggest that its energy would be barely sufficient to entrain dust and sand (Hansen et al., 2011; Diniega et al., 2013).

The investigated gullies are well-distributed over the mid-latitudes of the planets southern hemisphere. Therefore, it is reasonable to consider the interplay of primary and secondary processes inferred from our dataset as representative for the southern hemisphere mid-latitude gully population. We do not expect significant differences in the interplay of primary and secondary processes on northern hemisphere gullies, but this remains to be investigated.

\section{Conclusions}

We performed a combined analysis of gully-outcrop sedimentology and surface morphology to constrain the formative processes of martian gullies and to resolve the discrepancy between 
interpretations of gully-fan morphometry and surface morphology, suggesting dominant gully formation by debris flows and fluvial flows, respectively.

Analyses of outcrop sedimentology on gully-fans in 51 HiRISE images widely distributed over the southern midlatitudes shows that a majority of gullies dominantly formed by debris flows. The great majority (96\%) of exposures in gully-fans fed by catchments that mainly comprise bedrock, and thus contain many boulders, show typical debris-flow sedimentology; including many randomly distributed and oriented large boulders $(>1 \mathrm{~m})$ suspended in a finer matrix and lens-shaped and truncated layering. These key diagnostic features for debris-flow formation are rare in gully-fan exposures mainly fed by LDM catchments, as boulders are largely absent in these catchments. Probably, these gully-systems formed by fine-grained debris flows, but this cannot be determined from outcrop sedimentology alone. The gully-fan surfaces, in contrast to the subsurface, are dominated by secondary, post-depositional, processes, mainly wind erosion, weathering and ice-dust mantling. These processes have removed or severely reworked the original, primary, debris-flow morphology.

These combined observations from outcrop sedimentology and surface morphology provide an explanation for the discrepancy between previously published morphometric and morphological analyses. The inferred debris-flow origin for many gullies implies that the amounts of liquid water during gully-formation were ephemeral and limited.

\section{Acknowledgments}

This work is part of the PhD research of TdH, supported by the Netherlands Organisation for Scientific Research (NWO) and the Netherlands Space Office (NSO) (Grant ALW-GO-PL17-2012 to MGK). EH was partly supported by the Helmholtz Association through the research alliance Planetary Evolution and Life. SJC is funded by a Leverhulme Trust Grant RPG-397. Constructive comments by Joseph Levy and anonymous reviewer are gratefully acknowledged. The authors contributed in the following proportions to conception and design, data collection, analysis and conclusions, and manuscript preparation: $\mathrm{TdH}(70 \%, 80 \%, 50 \%, 70 \%)$, DV $(0 \%, 0 \%, 20 \%, 20 \%)$, EH $(10 \%, 0 \%, 10 \%, 10 \%)$, SJC (0\%, $20 \%, 0 \%$, $0 \%)$, MGK (20\%, 0\%, 20\%, 20\%).

\section{Appendix A. Boulder mobility over fan slopes}

Here, we present the methods used to evaluate the mobility of boulders in fluvial flows on steep gully slopes. Field and experimental data indicate that sediment transport is less efficient in steep channels, as compared to lowland rivers (e.g., Zimmermann and Church, 2001; Lenzi et al., 2006; Scheingross et al., 2013). This has been attributed to the presence of bedforms such as step pools, changes in the hydrodynamics of shallow, rough flows, incomplete submergence of grains during transport and large immobile grains that increase flow resistance (e.g., Yager et al., 2007; Lamb et al., 2008; Zimmermann et al., 2010; Prancevic et al., 2014). The stress exerted on a particle is given by the Shields number:

$\theta=\frac{\tau_{g}}{\left(\rho_{s}-\rho\right) g D}$

where $\rho_{\mathrm{s}}=$ sediment density $\left(3400 \mathrm{~kg} / \mathrm{m}^{3}\right.$ for basaltic rocks on Mars), $\rho=$ density of pure water $\left(1000 \mathrm{~kg} / \mathrm{m}^{3}\right), g=$ acceleration due to gravity $\left(3.74 \mathrm{~m} / \mathrm{s}^{2}\right.$ for Mars), $D=$ grain diameter at interest (in $\mathrm{m}$ ) and $\tau_{g}=$ total shear stress on the particles of interest on the bed:

$\tau_{T}=\tau_{g}+\tau_{m}+\tau_{w}$ wherein $\tau_{T}$ is the total driving stress at the bed, which is a sum of the stress spent on the channel walls $\tau_{w}$, bed morphology $\tau_{m}$ and the particles of interest at the bed $\tau_{g}$ (e.g., Einstein and Barbarossa, 1952; Vanoni and Brooks, 1957). For steady and uniform flows the total driving stress at the bed can be calculated as:

$\tau_{T}=\rho g h S$

wherein $h=$ water depth $(\mathrm{m})$ and $S=$ bed slope defined as $\sin (\beta)$, where $\beta$ = bed slope angle in degrees. In general, morphological and wall drag are neglected and the total shear stress on the particles of interest on the bed is considered equal to the total driving stress: $\tau_{g}=\tau_{T}$. Deposition by fluvial runoff on fans occurs generally as sheetfloods (Blair and McPherson, 2009), which are short-duration, catastrophic floods of unconfined water (Bull, 1972) that develop when confined runoff from the catchment expands over the fan surface. Flow expansion is promoted by the conical surface of the fans and begins either on the fan apex or on an active depositional lobe located downslope of an incised channel (Blair, 1987). Because discharge is distributed over relatively broad areas, sheetfloods often have limited depths, which are very rarely in excess of $1 \mathrm{~m}$ (Blair and McPherson, 1994). Given the unconfined nature of such events, wall drag can be neglected. However, morphological drag or form drag increases with increasing channel slope (e.g., Ferguson, 2012; Yager et al., 2012a), and is therefore non-negligible on steep gradients because of morphological structures like particle clusters (Brayshaw et al., 1983; Hassan and Reid, 1990; Yager et al., 2012b), immobile or protruding particles (Millar, 1999; Yager et al., 2007) and step-pools (Zimmermann and Church, 2001; Wilcox et al., 2006; Zimmermann et al., 2010). Similarly, unconfined sheetfloods generally encounter high morphological drag over fan surfaces, because of their complex morphology and generally coarse texture. Parker et al. (2007) found that morphological drag typically accounts for $21-57 \%$ of the total driving stress, and Lamb et al. (2008) found that morphological and wall drag together account between $0 \%$ and $60 \%$ of the total driving shear stress in natural streams and flume experiments, with a best fit at $40 \%$. Therefore, we define the total shear stress at the particles of interest at the bed as $\tau_{g}=0.6 \tau_{T}$. We calculate the critical Shields number for incipient motion via the method of Lamb et al. (2008) designed for steep streams, which takes into account slope-specific effects of a non-logarithmic vertical flow velocity profile, grain emergence, aeration of the flow and turbulence fluctuations at the bed:

$$
\begin{aligned}
\theta_{c r}= & \frac{h S}{r D}=\frac{2}{C_{D}} \frac{u_{\star}^{2}}{\left\langle u^{2}\right\rangle}\left(\frac{\tau}{\tau-\tau_{m}-\tau_{w}}\right)\left(\frac{\tan \left(\phi_{0}\right)-\tan (\beta)}{1+\left(F_{L} / F_{D} \tan \left(\phi_{0}\right)\right)}\right) \\
& \times\left[\frac{V_{p}}{A_{x S} D} \frac{1}{r}\left(\frac{\rho_{s}}{\rho}-\frac{V_{p s}}{V_{p}}\right)\right]
\end{aligned}
$$

where $r$ =specific submerged density $\left(\mathrm{kg} / \mathrm{m}^{3}\right)$ defined as $\left(\rho_{s}-\rho\right) / \rho, \phi_{0}=$ friction angle between grains in degrees $\left(\sim 50-70^{\circ}\right.$ for natural sediments (Miller and Byrne, 1966)), here set to $60^{\circ}$ as an intermediate estimate. $C_{D}$ is the drag coefficient on a particle. For flows over natural sediments $C_{D}$ is typically 0.45 (e.g., Recking, 2009); however for flows of low relative depth on steep slopes $C_{D}$ can reach up to 0.9 (e.g., Armanini and Gregoretti, 2005; Lamb et al., 2008). As an intermediate, we take $C_{D}=0.7$ as representative for steep gradients of martian gullies. The ratio between lift and drag forces is defined by $F_{L} / F_{D}$, and is typically set to 0.85 (e.g., Wiberg and Smith, 1987; Armanini and Gregoretti, 2005; Lamb et al., 2008). $V_{p}$ is the total volume of the particle $\left(\mathrm{m}^{3}\right) . V_{p s}$ is the submerged volume of the particle and equal to $V_{p}$ only when the particle is fully submerged. Likewise, $A_{x}$ is the total cross sectional area of the particle perpendicular to the main flow direction $\left(\mathrm{m}^{2}\right)$ and $A_{x s}$ is the cross sectional area of the particle that is perpendicular to and exposed to the flow, and does not include any portion 
of the particle that is emergent from the flow. We calculate $V_{p}, V_{p s}, A_{x}$ and $A_{x s}$ by assuming spherical particles, and the latter two are calculated by integrating a partial sphere (cf., Recking, 2009):

$A_{x}=\pi\left(\frac{D}{2}\right)^{2}$ for $h>D$

$V_{p}=\frac{4}{3} \pi\left(\frac{D}{2}\right)^{3}$ for $h>D$

$$
A_{x s}=\left[1-\frac{1}{\pi}\left(2 \frac{h}{D}-1\right)+\frac{4}{\pi}\left(\frac{h}{D}\right)^{2}\left(1-\frac{D}{2 h}\right) \sqrt{\frac{D}{h}-1}\right] A_{x} \text { for } h
$$

$V_{p s}=\left[1-2\left(1-\frac{h}{D}\right)^{2}\left(\frac{1}{2}+\frac{h}{D}\right)\right] V_{p} \quad$ for $h \leqslant D$

Lamb et al. (2008) employ a quadratic velocity profile for flow in steep streams:

$\frac{\bar{u}}{u_{\star}}=\frac{z}{\alpha_{1} k_{s}}\left[1-\left(\frac{z}{2 k_{s}} \frac{k_{s}}{h}\right)\right]$

where the shear velocity $u_{\star}=\sqrt{\tau_{g} / \rho_{w}}(\mathrm{~m} / \mathrm{s})$ and the coefficient $\alpha_{1}=$ 0.12 (Lamb et al., 2008). We define the bed roughness $k_{s}(\mathrm{~m})$ equal to $D$. The local velocity $\langle u\rangle(\mathrm{m} / \mathrm{s})$ is defined as the mean of the velocity profile integrated from $z_{0} \leqslant z \geqslant D$ for $h>D$ or $z_{0} \leqslant z \leqslant h$ for $h<D$, where $z_{0}=k_{s} / 30$. Prancevic et al. (2014) show that when bed Shields stress exceeds the critical Shields stress for bed failure, the entire bed becomes mobile and a debris flow is initiated. The critical Shields stress for bed failure $\theta_{b c r}$ is given by Takahashi (1978):

$\theta_{b c r}=(1-\eta)\left(\tan \phi_{f}-\tan \theta\right)-\frac{\rho}{\rho_{s}-\rho} \tan \theta$

where $\eta$ is bed porosity (-). Bed porosity typically ranges between 0.25 and 0.4 in natural streams (Kleinhans, 2005). For rounded, poorly sorted sediment bed porosity is typically 0.25 (on a scale $0-1$ ), but bed porosity can increase to 0.4 for clast-supported angular gravel (Allen, 1984). We employ $\eta=0.4$ for the most likely coarse and angular sediment on martian gullies, given the restricted transport distance and steep slopes. $\phi_{f}$ is the failure-plane friction angle, which ranges between $40^{\circ}$ and $60^{\circ}$ on Earth (Selby, 1993). As an intermediate estimate we set $\phi_{f}$ to $50^{\circ}$ for martian gullies (deviation by the lower martian gravity is unknown).

\section{Appendix B. Supplementary material}

Supplementary data associated with this article can be found, in the online version, at http://dx.doi.org/10.1016/j.icarus.2015.06. 017.

\section{References}

Al-Farraj, A., Harvey, A.M., 2000. Desert pavement characteristics on wadi terrace and alluvial fan surfaces: Wadi Al-Bih, U.A.E. and Oman. Geomorphology 35 (34), 279-297.

Allen, J.R.L., 1984. Sedimentary Structures, Their Character and Physical Basis. Elsevier, New York.

Anderson, S.P., Anderson, R.S., 1990. Debris-flow benches: Dune-contact deposits record paleo-sand dune positions in north Panamint Valley, Inyo County, California. Geology 18 (6), 524-527.

Armanini, A., Gregoretti, C., 2005. Incipient sediment motion at high slopes in uniform flow condition. Water Resour. Res. 41 (12), W12431. http://dx.doi.org/ 10.1029/2005WR004001.
Aston, A., Conway, S., Balme, M., 2011. Identifying martian gully evolution. Geol. Soc, Lond., Special Publ, 356 (1), 151-169.

Balme, M. et al., 2006. Orientation and distribution of recent gullies in the southern hemisphere of Mars: Observations from High Resolution Stereo Camera/Mars Express (HRSC/MEX) and Mars Orbiter Camera/Mars Global Surveyor (MOC) MGS) data. J. Geophys. Res.: Planets (1991-2012) 111 (E5). http://dx.doi.org/ 10.1029/2005JE002607.

Blair, T.C., 1987. Sedimentary processes, vertical stratification sequences, and geomorphology of the Roaring River alluvial fan, Rocky Mountain National Park, Colorado. J. Sediment. Res. 57 (1), 1-18.

Blair, T.C., 1999. Sedimentology of the debris-flow-dominated Warm Spring Canyon alluvial fan, Death Valley, California. Sedimentology 46 (5), 941-965.

Blair, T.C., 2003. Features and origin of the giant Cucomungo Canyon alluvial fan, Eureka Valley, California. Spec. Pap.-Geol. Soc. Am., 105-126

Blair, T.C., McPherson, J.G., 1994. Alluvial fans and their natural distinction from rivers based on morphology, hydraulic processes, sedimentary processes, and facies assemblages. J. Sediment. Res. 64A, 450-489.

Blair, T.C., McPherson, J.G., 1998. Recent debris-flow processes and resultant form and facies of the Dolomite alluvial fan, Owens Valley, California. J. Sediment. Res. 68 (5), 800-818.

Blair, T.C., McPherson, J.G., 2009. Processes and forms of alluvial fans. In: Parsons, A., Abrahams, A. (Eds.), Geomorphology of Desert Environments. Springer, Netherlands, pp. 413-467.

Blikra, L.H., Nemec, W., 1998. Postglacial colluvium in western Norway: Depositional processes, facies and palaeoclimatic record. Sedimentology 45 (5), 909-960.

Bluck, B., 1979. Structure of coarse grained braided stream alluvium. Trans. Roy. Soc. Edinburgh 70 (10-12), 181-221.

Brayshaw, A.C., Frostick, L.E., Reid, I., 1983. The hydrodynamics of particle clusters and sediment entrapment in coarse alluvial channels. Sedimentology 30 (1) 137-143.

Bridges, N. et al., 2012a. Earth-like sand fluxes on Mars. Nature 485 (7398), 339_ 342.

Bridges, N.T. et al., 2012b. Planet-wide sand motion on Mars. Geology 40 (1), 31-34.

Brierley, G.J., 1996. Channel morphology and element assemblages: A constructivist approach to facies modelling. Adv. Fluv. Dynam. Stratigr., 263-298

Bull, W.B., 1972. Recognition of Alluvial Fan Deposits in the Stratigraphic Record Special Publications of SEPM.

Caine, N., 1980. The rainfall intensity-duration control of shallow landslides and debris flows. Geografiska Annaler A 62 (1-2), 23-27.

Cedillo-Flores, Y. et al., 2011. $\mathrm{CO}_{2}$ gas fluidization in the initiation and formation of martian polar gullies. Geophys. Res. Lett. 38 (21), L21202.

Christensen, P.R., 2003. Formation of recent martian gullies through melting of extensive water-rich snow deposits. Nature 422 (6927), 45-48.

Collinson, J.D., 1970. Bedforms of the Tana river, Norway. Geografiska Annaler. Ser A. Phys. Geogr. 52, 31-56.

Conway, S.J., 2010. Debris Flows on Earth and Mars, Ph.D. thesis. Open University.

Conway, S.J. et al., 2011. The indication of martian gully formation processes by slope-area analysis. Geol. Soc., Lond., Spec. Publ. 356 (1), 171-201.

Conway, S.J. et al., 2015. The comparison of topographic long profiles of gullies on Earth to gullies on Mars: A signal of water on Mars. Icarus 253, 189-204.

Copons, R., Vilaplana, J., Linares, R., 2009. Rockfall travel distance analysis by using empirical models (Solà d'Andorra la Vella, Central Pyrenees). Nat. Hazards Earth Syst. Sci. 9, 2107-2118.

Costa, J.E., 1988. Rheologic, geomorphic, and sedimentologic differentiation of water floods, hyperconcentrated flows, and debris flows. Flood Geomorphol. 113-122

Costard, F. et al., 2002. Formation of recent martian debris flows by melting of nearsurface ground ice at high obliquity. Science 295 (5552), 110-113.

Crosta, G.B., Frattini, P., 2004. Controls on modern alluvial fan processes in the central Alps, northern Italy. Earth Surf. Process. Landforms 29 (3), 267-293.

De Haas, T., Hauber, E., Kleinhans, M.G., 2013. Local late Amazonian boulder breakdown and denudation rate on Mars. Geophys. Res. Lett. 40. http:// dx.doi.org/10.1002/grl.50726.

De Haas, T. et al., 2014. Debris-flow dominance of alluvial fans masked by runoff reworking and weathering. Geomorphology 217, 165-181.

De Haas, T. et al., 2015a. Surface morphology of fans in the high-arctic periglacial environment of Svalbard: Controls and processes. Earth Sci. Rev. 146, 163182.

De Haas, T. et al., 2015b. Earth-like aqueous debris-flow activity on Mars at high orbital obliquity in the last million years. Nat. Commun. 6. http://dx.doi.org/ 10.1038/ncomms8543, article number: 7543.

Dickson, J.L., Head, J.W., 2009. The formation and evolution of youthful gullies on Mars: Gullies as the late-stage phase of Mars most recent ice age. Icarus 204 (1) $63-86$.

Dickson, J.L., Head, J.W., Kreslavsky, M., 2007. Martian gullies in the southern midlatitudes of Mars: Evidence for climate-controlled formation of young fluvial features based upon local and global topography. Icarus 188 (2), 315-323.

Diniega, S. et al., 2010. Seasonality of present-day martian dune-gully activity. Geology 38 (11), 1047-1050.

Diniega, S. et al., 2013. A new dry hypothesis for the formation of martian linear gullies. Icarus 225 (1), 526-537.

Dorn, R.I., 1994. The role of climatic change in alluvial fan development. In: Geomorphology of Desert Environments. Springer, pp. 593-615.

Dorren, L. et al., 2011. Methods for predicting rockfall trajectories and run-out zones. Rock. Eng., 143-173 
Dundas, C.M. et al., 2010. New and recent gully activity on Mars as seen by HiRISE. Geophys. Res. Lett. 37 (7), L07202.

Dundas, C.M. et al., 2012. Seasonal activity and morphological changes in martian gullies. Icarus 220 (1), 124-143.

Dundas, C.M., Diniega, S., McEwen, A.S., 2014. Long-term monitoring of martian gully formation and evolution with MRO/HiRISE. Icarus 251, 244-263.

Einstein, H.A., Barbarossa, N.L., 1952. River channel roughness. Trans. Am. Soc. Civil Eng. 117 (1), 1121-1132.

Evans, S., Hungr, O., 1993. The assessment of rockfall hazard at the base of talus slopes. Can. Geotech. J. 30 (4), 620-636.

Ferguson, R.I., 2012. River channel slope, flow resistance, and gravel entrainment thresholds. Water Resour. Res. 48 (5), W05517. http://dx.doi.org/10.1029/ 2011WR010850.

Fisher, R.V., 1971. Features of coarse-grained, high-concentration fluids and their deposits. J. Sediment. Res. 41 (4), 916-927.

Frankel, K.L., Dolan, J.F., 2007. Characterizing arid region alluvial fan surface roughness with airborne laser swath mapping digital topographic data. J. Geophys. Res. 112 (F2), F02025.

Geissler, P. et al., 2010. Gone with the wind: Eolian erasure of the Mars Rover tracks. J. Geophys. Res.: Planets (1991-2012) 115 (E7). http://dx.doi.org/10.1029/ 2010JE003674.

Golombek, M. et al., 2010. Constraints on ripple migration at Meridiani Planum from Opportunity and HiRISE observations of fresh craters. J. Geophys. Res. Planets 115 (E7). http://dx.doi.org/10.1029/2010JE003628.

Golombek, M.P. et al., 2014. Small crater modification on meridiani planum and implications for erosion rates and climate change on Mars. J. Geophys. Res.: Planets 119. http://dx.doi.org/10.1002/2014JE004658.

Grindrod, P.M., Warner, N., 2014. Erosion rate and previous extent of interior layered deposits on Mars revealed by obstructed landslides. Geology 42 (9), $795-798$

Grotzinger, J.P., Milliken, R.E., 2012. The sedimentary rock record of Mars: Distribution, origins, and global stratigraphy. Sediment. Geol. Mars, 1-48.

Hansen, C. et al., 2011. Seasonal erosion and restoration of Mars' northern polar dunes. Science 331 (6017), 575-578.

Hartley, A.J. et al., 2005. Alluvial Fans: Geomorphology, Sedimentology, Dynamics. Geological Society London Special Publication (Ch. Climatic controls on alluvialfan activity, Coastal Cordillera, northern Chile, pp. 95-115).

Hartmann, W.K., Thorsteinsson, T., Sigurdsson, F., 2003. Martian hillside gullies and Icelandic analogs. Icarus 162 (2), 259-277.

Harvey, A.M., 2010. Sediment Cascades: An Integrated Approach. John Wiley \& Sons, Ltd (Ch. Local Buffers to the Sediment Cascade: Debris Cones and Alluvial Fans, pp. 153-180).

Harvey, A., 2011. Dryland alluvial fans. Arid Zone Geomorphol.: Process, Form Change Drylands, Third Ed., pp. 333-371.

Hassan, M.A., Reid, I., 1990. The influence of microform bed roughness elements on flow and sediment transport in gravel bed rivers. Earth Surface Process. Landforms 15 (8), 739-750.

Head, J.W. et al., 2003. Recent ice ages on Mars. Nature 426, 797-802.

Head, J.W., Marchant, D.R., Kreslavsky, M.A., 2008. Formation of gullies on Mars: Link to recent climate history and insolation microenvironments implicate surface water flow origin. Proc. Nat. Acad. Sci. 105 (36), 13258-13263.

Hecht, M.H., 2002. Metastability of liquid water on mars. Icarus 156 (2), 373-386.

Heim, A., 1932. Bergsturz und menschenleben, vol. 30. Fretz \& Wasmuth.

Heldmann, J.L., Mellon, M.T., 2004. Observations of martian gullies and constraints on potential formation mechanisms. Icarus 168 (2), 285-304.

Heldmann, J.L. et al., 2005. Formation of martian gullies by the action of liquid water flowing under current martian environmental conditions. J. Geophys. Res. 110 (E5), E05004.

Holbrook, J., 2001. Origin, genetic interrelationships, and stratigraphy over the continuum of fluvial channel-form bounding surfaces: An illustration from middle Cretaceous strata, southeastern Colorado. Sediment. Geol. 144 (3), 179222.

Horton, B., DeCelles, P., 2001. Modern and ancient fluvial megafans in the foreland basin system of the central Andes, southern Bolivia: Implications for drainage network evolution in fold-thrust belts. Basin Res. 13 (1), 43-63.

Hubert, J.F., Filipov, A.J., 1989. Debris-flow deposits in alluvial fans on the west flank of the White Mountains, Owens Valley, California, USA. Sediment. Geol. 61 (3), 177-205.

Iverson, R.M., 1997. The physics of debris flows. Rev. Geophys. 35 (3), 245-296.

Johnson, C. et al., 2012. Grain-size segregation and levee formation in geophysical mass flows. J. Geophys. Res.: Earth Surface (2003-2012) 117 (F1). http:/ dx.doi.org/10.1029/2011JF002185.

Johnsson, A. et al., 2014. Evidence for very recent melt-water and debris flow activity in gullies in a young mid-latitude crater on Mars. Icarus 235, 37-54.

Kirk, R. et al., 2008. Ultrahigh resolution topographic mapping of Mars with MRO HiRISE stereo images: Meter-scale slopes of candidate Phoenix landing sites. J. Geophys. Res.: Planets (1991-2012) 113 (E3). http://dx.doi.org/10.1029/ 2007JE003000

Kleinhans, M.G., 2005. Flow discharge and sediment transport models for estimating a minimum timescale of hydrological activity and channel and delta formation on Mars. J. Geophys. Res. - Planet 110 (E12). http://dx.doi.org/ 10.1029/2005JE002521.

Kneissl, T. et al., 2010. Distribution and orientation of northern-hemisphere gullies on Mars from the evaluation of HRSC and MOC-NA data. Earth Planet. Sci. Lett. 294 (3), 357-367.
Lamb, M.P., Dietrich, W.E., Venditti, J.G., 2008. Is the critical Shields stress for incipient sediment motion dependent on channel-bed slope? J. Geophys. Res. Earth Surface (2003-2012) 113 (F2), F02008.

Lanza, N. et al., 2010. Evidence for debris flow gully formation initiated by shallow subsurface water on Mars. Icarus 205 (1), 103-112.

Lenzi, M., Mao, L., Comiti, F., 2006. When does bedload transport begin in steep boulder-bed streams? Hydrol. Process. 20 (16), 3517-3533.

Levy, J. et al., 2009a. Geologically recent gully-polygon relationships on Mars: Insights from the Antarctic Dry Valleys on the roles of permafrost, microclimates, and water sources for surface flow. Icarus 201 (1), 113-126.

Levy, J.S., Head, J.W., Marchant, D.R., 2009b. Cold and dry processes in the martian Arctic: Geomorphic observations at the Phoenix landing site and comparisons with terrestrial cold desert landforms. Geophys. Res. Lett. 36 (21), L21203.

Levy, J. et al., 2010. Identification of gully debris flow deposits in Protonilus Mensae, Mars: Characterization of a water-bearing, energetic gully-forming process. Earth Planet. Sci. Lett. 294 (34), 368-377.

Lied, K., 1977. Rockfall problems in Norway. Rockfall Dynamics and Protective Work Effectiveness, vol. 90. ISMES publ., pp. 51-53.

Madeleine, J.-B. et al., 2009. Amazonian northern mid-latitude glaciation on Mars: A proposed climate scenario. Icarus 203 (2), 390-405.

Madeleine, J.-B. et al., 2014. Recent Ice Ages on Mars: The role of radiatively active clouds and cloud microphysics. Geophys. Res. Lett. 41 (14), 4873-4879.

Major, J.J., 1997. Depositional processes in large-scale debris-flow experiments. J. Geol. 105 (3), 345-366.

Major, J.J., Iverson, R.M., 1999. Debris-flow deposition: Effects of pore-fluid pressure and friction concentrated at flow margins. Geol. Soc. Am. Bullet. 111 (10), 1424 1434.

Malin, M.C., Edgett, K.S., 2000. Evidence for recent groundwater seepage and surface runoff on Mars. Science 288 (5475), 2330-2335.

Mangold, N., 2005. High latitude patterned grounds on Mars: Classification, distribution and climatic control. Icarus 174 (2), 336-359.

Mangold, N. et al., 2004. Spatial relationships between patterned ground and ground ice detected by the Neutron Spectrometer on Mars. J. Geophys. Res.: Planets (1991-2012) 109 (E8). http://dx.doi.org/10.1029/2004JE002235.

Mangold, N. et al., 2010. Sinuous gullies on Mars: Frequency, distribution, and implications for flow properties. J. Geophys. Res.: Planets (1991-2012) 115 (E11). http://dx.doi.org/10.1029/2009JE003540.

McEwen, A.S. et al., 2005. The rayed crater Zunil and interpretations of small impact craters on Mars. Icarus 176 (2), 351-381.

McFadden, L.D., Wells, S.G., Jercinovich, M.J., 1987. Influences of eolian and pedogenic processes on the origin and evolution of desert pavements. Geology 15 (6), 504-508.

Miall, A.D., 1988. Architectural elements and bounding surfaces in fluvial deposits: Anatomy of the Kayenta Formation (Lower Jurassic), southwest Colorado. Sediment. Geol. 55 (3), 233-262.

Millar, R.G., 1999. Grain and form resistance in gravel-bed rivers. J. Hydraul. Res. 37 (3), 303-312.

Miller, R.L., Byrne, R.J., 1966. The angle of repose for a single grain on a fixed rough bed. Sedimentology 6 (4), 303-314.

Milliken, R., Mustard, J., Goldsby, D., 2003. Viscous flow features on the surface of Mars: Observations from high-resolution Mars Orbiter Camera (MOC) images. J. Geophys. Res.: Planets (1991-2012) 108 (E6). http://dx.doi.org/10.1029/ 2002JE002005.

Morgan, A. et al., 2014. Sedimentology and climatic environment of alluvial fans in the martian Saheki crater and a comparison with terrestrial fans in the Atacama Desert. Icarus 229, 131-156.

Mustard, J.F., Cooper, C.D., Rifkin, M.K., 2001. Evidence for recent climate change on Mars from the identification of youthful near-surface ground ice. Nature 412 (6845), 411-414.

Pain, C., Clarke, J., Thomas, M., 2007. Inversion of relief on Mars. Icarus 190 (2), 478491.

Parker, G. et al., 2007. Physical basis for quasi-universal relations describing bankfull hydraulic geometry of single-thread gravel bed rivers. J. Geophys. Res.: Earth Surface (2003-2012) 112 (F4), F04005.

Pelletier, J.D., 2007. Cantor set model of eolian dust deposits on desert alluvial fan terraces. Geology 35 (5), 439-442.

Pelletier, J.D. et al., 2008. Recent bright gully deposits on Mars: Wet or dry flow? Geology 36 (3), 211-214.

Pierson, T.C., 1980. Erosion and deposition by debris flows at Mt. Thomas, North Canterbury, New Zealand. Earth Surface Process. 5 (3), 227-247.

Pierson, T.C., 2005. Distinguishing Between Debris Flows and Floods From Field Evidence in Small Watersheds. US Department of the Interior, US Geological Survey.

Pierson, T.C., Costa, J.E., 1987. A rheologic classification of subaerial sediment-water flows. Rev. Eng. Geol. 7, 1-12.

Prancevic, J.P., Lamb, M.P., Fuller, B.M., 2014. Incipient sediment motion across the river to debris-flow transition. Geology 42 (3), 191-194.

Recking, A., 2009. Theoretical development on the effects of changing flow hydraulics on incipient bed load motion. Water Resour. Res. 45 (4), W04401. http://dx.doi.org/10.1029/2008WR006826.

Reiss, D. et al., 2004. Absolute dune ages and implications for the time of formation of gullies in Nirgal Vallis, Mars. J. Geophys. Res.: Planets 109 (E6). http:// dx.doi.org/10.1029/2004JE002251.

Reiss, D. et al., 2011. Terrestrial gullies and debris-flow tracks on Svalbard as planetary analogs for Mars. Geol. Soc. Am. Spec. Pap. 483, 165-175. 
Scheingross, J.S. et al., 2013. Influence of bed patchiness, slope, grain hiding, and form drag on gravel mobilization in very steep streams. J. Geophys. Res.: Earth Surface 118 (2), 982-1001.

Schon, S.C., Head, J.W., Fassett, C.I., 2009. Unique chronostratigraphic marker in depositional fan stratigraphy on Mars: Evidence for ca. 1.25 Ma gully activity and surficial meltwater origin. Geology 37, 207-210.

Scott, K.M., Vallance, J., Pringle, P.T., 1995. Sedimentology, Behavior, and Hazards of Debris Flows at Mount Rainier, Washington. U.S. Geological Survey Professional Paper 1547.

Selby, M., 1993. Hillslope materials and processes, 1993.

Suwa, H., 1988. Focusing mechanism of large boulders to a debris-flow front. Trans. Japan. Geomorphol. Union 9, 151-178.

Suwa, H., Okuda, S., 1983. Deposition of debris flows on a fan surface, Mt. Yakedake, Japan. Zeitschrift fur Geomorphologie NF Supplementband 46, 79-101.

Takahashi, T., 1978. Mechanical aspects of debris flow. J. Hydraul. Div., Am. Soc. Civil Eng. Proc. 104, 1153-1169.

Todd, S.P., 1996. Process Deduction From Fluvial Sedimentary Structures. Advances in Fluvial Dynamics and Stratigraphy. Wiley, Chichester, pp. 299-350.

Treiman, A.H., 2003. Geologic settings of martian gullies: Implications for their origins. J. Geophys. Res.: Planets (1991-2012) 108 (E4). http://dx.doi.org/ 10.1029/2002JE001900.

Vallance, J.W., Scott, K.M., 1997. The Osceola Mudflow from Mount Rainier: Sedimentology and hazard implications of a huge clay-rich debris flow. Geol. Soc. Am. Bullet. 109 (2), 143-163.

Vanoni, V.A., Brooks, N.H., 1957. Laboratory Studies of the Roughness and Suspended Load of Alluvial Streams. California Institute of Technology Sedimentation Laboratory.

Ventra, D., Diaz, G.C., de Boer, P.l., 2013. Colluvial sedimentation in a hyperarid setting (Atacama Desert, northern Chile): Geomorphic controls and stratigraphic facies variability. Sedimentology 60, 1257-1290.

Volker, H., Wasklewicz, T., Ellis, M., 2007. A topographic fingerprint to distinguish alluvial fan formative processes. Geomorphology 88 (12), 34-45.

Wells, S.G., McFadden, L.D., Dohrenwend, J.C., 1987. Influence of late Quaternary climatic changes on geomorphic and pedogenic processes on a desert piedmont, Eastern Mojave Desert, California. Quart. Res. 27 (2), 130-146.
Welsh, A., Davies, T., 2011. Identification of alluvial fans susceptible to debris-flow hazards. Landslides 8 (2), 183-194.

Whipple, K.X., Dunne, T., 1992. The influence of debris-flow rheology on fan morphology, Owens Valley, California. Geol. Soc. Am. Bullet. 104 (7), 887-900.

Wiberg P.L., Smith, J.D. 1987. Calculations of the critical shear stress for motion of uniform and heterogeneous sediments. Water Resour. Res. 23 (8), 1471-1480.

Wieczorek, G. et al., 2008. Investigation and hazard assessment of the 2003 and 2007 Staircase Falls rock falls, Yosemite National Park, California, USA. Nat. Hazards Earth Syst. Sci. 8 (3), 421-432.

Wilcox, A.C., Nelson, J.M., Wohl, E.E., 2006. Flow resistance dynamics in step-poo channels: 2. Partitioning between grain, spill, and woody debris resistance. Water Resour. Res. 42 (5), W05419. http://dx.doi.org/10.1029/2005WR004278.

Wilford, D. et al., 2004. Recognition of debris flow, debris flood and flood hazard through watershed morphometrics. Landslides 1 (1), 61-66.

Wilkinson, J.M., Marshall, L.G., Lundberg, J.G., 2006. River behavior on megafans and potential influences on diversification and distribution of aquatic organisms. J. South Am. Earth Sci. 21 (1), 151-172.

Williams, K. et al., 2009. Ancient melting of mid-latitude snowpacks on Mars as a water source for gullies. Icarus 200 (2), 418-425.

Williams, R. et al., 2013. Martian fluvial conglomerates at Gale crater. Science 340 (6136), 1068-1072.

Yager, E. et al., 2012a. Prediction of sediment transport in step-pool channels. Water Resour. Res. 48 (1), W01541. http://dx.doi.org/10.1029/2011WR010829.

Yager, E. et al., 2012b. Sediment supply, grain protrusion, and bedload transport in mountain streams. Geophys. Res. Lett. 39 (10), L10402.

Yager, E., Kirchner, J., Dietrich, W., 2007. Calculating bed load transport in steep boulder bed channels. Water Resour. Res. 43 (7), W07418. http://dx.doi.org/ 10.1029/2006WR005432.

Yue, Z. et al., 2014. Quantitative analysis of the morphology of martian gullies and insights into their formation. Icarus 243, 208-221.

Zimmermann, A., Church, M., 2001. Channel morphology, gradient profiles and bed stresses during flood in a step-pool channel. Geomorphology 40 (3), 311-327.

Zimmermann, A., Church, M., Hassan, M.A. 2010. Step-pool stability: Testing the jammed state hypothesis. J. Geophys. Res.: Earth Surface (2003-2012) 115 (F2), F02008. 